\title{
Ediacaran Microfossils from the Ura Formation, Baikal-Patom Uplift, Siberia: Taxonomy and Biostratigraphic Significance
}

\section{Citation}

Sergeev, Vladimir N., Andrew H. Knoll, and Natalya G. Vorob'Eva. 2011. “Ediacaran Microfossils from the Ura Formation, Baikal-Patom Uplift, Siberia: Taxonomy and Biostratigraphic Significance." Journal of Paleontology 85, no. 5: 987-1011.

\section{Published Version}

doi:10.1666/11-022.1

\section{Permanent link}

http://nrs.harvard.edu/urn-3:HUL.InstRepos:13041341

\section{Terms of Use}

This article was downloaded from Harvard University's DASH repository, and is made available under the terms and conditions applicable to Open Access Policy Articles, as set forth at http:// nrs.harvard.edu/urn-3:HUL.InstRepos:dash.current.terms-of-use\#OAP

\section{Share Your Story}

The Harvard community has made this article openly available.

Please share how this access benefits you. Submit a story.

\section{Accessibility}


Running Head: Ediacaran Microfossils from Siberia

Key Words: Ediacaran, microfossils, biostratigraphy, Baikal-Patom Uplift, Siberia

EDIACARAN MICROFOSSILS FROM THE URA FORMATION, BAIKAL-

PATOM UPLIFT, SIBERIA: TAXONOMY AND BIOSTRATIGRAPHIC SIGNIFICANCE

VLADIMIR N. SERGEEV, ${ }^{1}$ ANDREW H. KNOLL, ${ }^{2}$ AND NATALYA G. VOROB’EVA ${ }^{1}$

${ }^{1}$ Geological Institute, Russian Academy of Sciences, Pyzhevskii per., 7, Moscow,

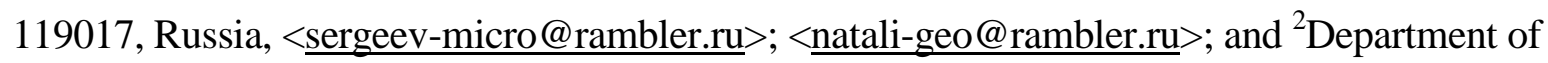
Organismic and Evolutionary Biology, Harvard University, 26 Oxford Street, Cambridge, MA 02138, USA, <aknoll@oeb.harvard.edu>

ABSTRACT-Abundant and diverse microfossils from shales of the uppermost Ura Formation, central Siberia, document early to middle Ediacaran life along the southeastern margin of the Siberian Platform. The Ura Formation is well exposed in a series of sections in the Lena River basin, but the best microfossil assemblages come from a locality along the Ura River. Here, the uppermost twenty meters of the formation contain diverse microfossils exceptionally well preserved as organic compressions. Fossils include nearly two dozen morphospecies of large acanthomorphic microfossils attributable to the Ediacaran Complex Acanthomorph Palynoflora (ECAP), a distinctive assemblage known elsewhere only from lower, but not lowermost, to middle Ediacaran rocks. Discovery of ECAP in strata previously considered Mesoproterozoic through Cryogenian confirms inferences from chemostratigraphy, dramatically changing stratigraphic interpretation of sedimentary 
successions and Proterozoic tectonics on the Siberian Platform. Systematic paleontology is reported for 36 taxa (five described informally) assigned to 23 genera of both eukaryotic and prokaryotic microfossils. One new genus and two new species are proposed:

Ancorosphaeridium magnum n. gen. n. sp. and A. minor n. gen. n. sp.

\section{INTRODUCTION}

EARLY RESEARCH painted Ediacaran microfossils as a depauperate assemblage of cyanobacteria and simple leiospherids, with limited biostratigraphic potential (e.g., Volkova et al., 1979; Volkova, 1985). Continuing discovery, however, has shown that Ediacaran rocks contain uniquely diverse assemblages of large ornamented cysts, permitting not only the characterization of a discrete time interval but its potential subdivision into a number of biostratigraphic zones (Grey, 2005, and references therein). It now appears that for the most part depauperate and diverse Ediacaran assemblages are separated in time, with ornamented cysts diversifying after the beginning of the Ediacaran Period and largely disappearing before its final nine million years (e.g., Vorob’eva et al., 2009b).

Diverse Ediacaran microfossils are known from a number of localities along the margins of the East European Platform and the Siberian craton, affording an opportunity to investigate the stratigraphic and geographic ranges of key taxa within and between cratons. Here we contribute to this effort, describing in systematic detail a previously reported (Vorob’eva et al., 2008) assemblage of Ediacaran microfossils from the Ura Formation (Dalnyaya Taiga Group, Patom Supergroup) and placing it in the context of stratigraphic development on the Siberian craton. 
Geographic and stratigraphic setting.-The Baikal-Patom Uplift (Fig. 1a) is located within the Patom-Zhuya and Ura structural-facies zones of the Sayan-Baikal foldbelt, a feature that extends southward from the Sayan Mountains of Buryatia to Lake Baikal before turning northward into southern Yakutia (Melnikov, 2005, p. 340, fig. 9). In overall structure, the Ura zone comprises a series of linked anti- and synclines, with the fossiliferous shales reported here exposed repeatedly in a southeastward plunging anticline in the Ura River valley (Fig. 1b). Sedimentary infill of the Baikal-Patom basin spans much of the interval from Mesoproterozoic to early Paleozoic (Golovenok, 1957; Chumakov, 1959; Bobrov, 1964; Salop, 1964; Khomentovsky et al., 1972; Livshic et al., 1995; Melnikov, 2005).

All fossils reported here occur in carbonaceous shales of the Ura Formation, a moderately thick platform succession divided into two members. The 250-m-thick Lower Member consists of fine-grained sandstones, siltstones and shales with intercalated lenses of dolomite. The 100- to-120-m-thick Upper Member displays gray and greenish-gray siltstones and shales, with thin interbedded limestone. Shale samples were collected through the entire Ura Formation on both limbs of the Ura anticline (Fig. 1b). Poorly preserved microfossils occur in almost every sample, but exceptionally well-preserved assemblages are restricted to a 20 m thick unit in the uppermost part of formation (Fig. 2a) that contains gray, laminated, clay-rich siltstones and shales, along with several 1-1.5 m thick beds of black laminated (partially recrystallized) limestones and dolomites (Fig. 2b).

Depositional environments. - Strata of the Ura Formation accumulated in a shallow shelf marine environment (Melnikov, 2005). In general, the succession deepens upward from coastal arenites and siltstones to shales deposited below fair-weather wave base (Chumakov et al., 2007). The upper Ura Formation is interpreted as a transgressive systems tract, transitional into highstand deposition across the formation's upper boundary. Deposition of overlying Kalancha Formation carbonates coincided with maximum flooding of the northern Siberian craton in early-middle Ediacaran time, which restricted the transport of siliciclastic 
sediments onto the marginal shelf (cf. Grotzinger, 1989). Siliciclastic-to-carbonate "grand cycles" have been previously documented in Cambrian (Aitken, 1978), Mesoproterozoic (Sergeev et al., 1995) and Paleoproterozoic (Grotzinger, 1986) marginal platforms adjacent to craton-interior siliciclastic source areas.

Microfossils reflect a mixture of benthic elements preserved in situ or nearly so, fragmental cyanobacterial mats transported from an inshore source (see Moczydłowska, 2008 for details), and cysts that represent a resting stage in the life cycles of organisms that lived on the seafloor or within the overlying water column (see Cohen et al., 2009, for discussion and further references). This being the case, we cannot assume that all populations formed part of a single community. All, however, provide information on shallow shelf ecosystems in Ediacaran oceans.

Depositional Age.—Fossiliferous Ura shales are part of the Dalnyaya Taiga Group, a $\sim 3 \mathrm{~km}$ succession of carbonates and fine-grained siliciclastic lithologies that lie above a basal diamictite (Fig. 2a). Overlying strata of the Tinnaya Formation contain small shelly fossils assigned to the Anabarites trisulcatus and (?)Purella antiqua zones of the basal Cambrian Nemakit-Daldyn (Manykaian) Stage (Missarzhevskii, 1989). Faunas typical of Lower Cambrian (Tommotian) Ajacicyathus sunnaginicus zone occur in carbonates of the immediately overlying Nokhtuisk Formation (Khomentovsky et al., 2004). Thus, the age of the Ura microfossils is bracketed by Neoproterozoic glaciation and the beginning of the Cambrian Period. The only meaningful radiometric constraint comes from detrital zircons, which provide a minimum depositional date of 646.9 +/-3.4 Ma (U-Pb; Chumakov et al., 2011) for the lower Nikolsk Formation, some 500 m above the fossiliferous Ura beds.

Originally, Dalnyaya Taiga diamictites were correlated with Sturtian glaciogenic rocks in Australia, Rapitan tillites in Canada, and other units representing earlier Neoproterozoic glaciation (Chumakov, 2001). More recently, however, high resolution C and Sr isotopic chemostratigraphy has shown that the tillites are capped by a cap carbonate 
similar to those above Marinoan-equivalent tillites deposited elsewhere. Moreover, coupled $\mathrm{C}$ and Sr isotopic data show a pattern of secular variation in the Dalnyaya Taiga and overlying successions that closely matches those of early to mid-Ediacaran rocks on other continents (Sovietov, 2002; Pokrovskii et al., 2006; Chumakov et al., 2007). This includes not only a negative C-isotopic anomaly in cap carbonates above the diamictite, but also a pronounced negative C-isotopic excursion in carbonates of the Zhuya Group that immediately overlie Dalnyaya Taiga strata, and a pattern of increasing ${ }^{87} \mathrm{Sr} /{ }^{86} \mathrm{Sr}$ from about 0.70725 to 0.70799 through the two groups (Pokrovskii et al., 2006). The interpretation of strong negative C-isotopic excursions in Ediacaran successions has been the subject of recent debate (e.g., Derry, 2010), but an isotopic excursion of unusual magnitude occurs essentially globally in Ediacaran successions older than 551 Ma (Condon et al., 2005).

Taken at face value, then, $\mathrm{C}$ and $\mathrm{Sr}$ isotopes indicate that fossiliferous Ura shales were deposited in early but not earliest Ediacaran times, and predate most known Ediacaran macrofossil deposits. As discussed below, biostratigraphic interpretation of Ura microfossils leads to the same conclusion.

\section{MATERIALS AND METHODS}

Fossiliferous locality.-The Ura microfossils reported here occur in shale samples collected from an outcrop in the upper stream of the Lena River at the stratigraphic section shown in Figures 1 and 2. Samples containing an abundant microfossil assemblage were taken in 2005 by N.M. Chumakov in the stratotype section on the Ura River (left tributary of the Lena River located $15 \mathrm{~km}$ upstream of the Chapaevo Settlement) at an exposure on the right bank 5.5 km from the river’s mouth (outcrop 1, Google Map Coordinates, decimal degrees latitude and longitude, 43.4618N, 69.8688E, samples 14701/1-12). Sampling was 
carried out at $\sim 1$ m intervals from a 20 m unit near the top of the formation of the Ura Formation section (Fig. 2b).

Repository of illustrated specimens.-All specimens discussed and illustrated here are reposited in the Paleontological Collection of the Geological Institute of the Russian Academy of Sciences (PCGIN of RAS), Collection \# 14701.

Methods of slide preparation and investigation.--Microfossils were extracted from the shales by low agitation processing. After standard processing of samples by caustic potash about $10 \%$ concentration (roughly one table spoon per $100 \mathrm{ml}$ of water) the shales were dissolved in hydrofluoric acid (100\%) and from the residue acritarchs and other microfossils were picked manually by needle using a stereomicroscope. This simple and effective technique avoids the need for centrifuging and heavy liquid treatment, facilitating the intact preservation of large microfossils (e.g., Grey, 1999, 2005; Willman and Moczydłowska, 2008). Slide-preparation methods were similar to those described in many publications; permanent strew mounts were made using Canadian balm mixed with polypropylene ether to inhibit recrystallization.

Transmitted-light photomicrographs were acquired using a RME-5 microscope (Rathenower, Germany) equipped with a Canon EOS 300D digital camera (Canon, Tokyo, Japan) and a Zeiss Axio Imager.A1 microscope (\#3517002390) equipped with an AxioCam MRc 5 digital camera (both Carl Zeiss, Germany). Specimen- and cell-sizes reported here were measured to the nearest micron using an eyepiece reticule, typically with a 40x objective.

\section{MICROFOSSILS OF THE URA FORMATION: TAXONOMY AND BIOLOGICAL INTERPRETATION}

The taxonomic composition of Ura microfossil assemblage is shown in Figure 3. The 36 distinct entities recognized here and in previous publications can be divided into four 
main morphological categories: acanthomorph acritarchs, spheromorph and netromorph acritarchs, filamentous microfossils, and miscellaneous forms. Many of the spheromorphic and filamentous taxa have long stratigraphic ranges, for example such typical Meso- and Neoproterozoic forms as Leiosphaeridia and Aimia. In contrast, the acanthomorphic acritarchs have limited ranges that facilitate biostratigraphic correlation.

Acanthomorph acritarchs. - Throughout the Ura Formation, the most abundant fossils are simple leiosphaerid acritarchs and empty sheaths of cyanobacteria, but acanthomorphic acritarchs are also abundant and moderately diverse. We recognize formally 19 morphotaxa of acanthomorphs with symmetrically or, in some cases, sparse and irregularly distributed processes. Two species described as new are arguably the most distinctive elements of the Ura acritarch assemblage. Ancorosphaeridium magnum (Figs. 4.1-4.3) is a large spheroidal vesicle with a moderate number of long hollow processes with anchor-like terminations - reminiscent of microbial grapnel hooks. Ancorosphaeridium minor (Fig. 4.4, 4.5) displays a similarly distinctive process morphology, but at a much smaller size.

Other taxa are well known from previous reports of Ediacaran micropaleontology. For example, the genus Appendisphaera, here represented by A. tenuis (Fig. 5.4-5.6, for illustrations of taxa see figure numbers in Systematic Section) and Appendisphaera sp. (Fig. 5.1-5.3) is well known from more distant parts of Siberia (Moczydłowska, 2005) and other continents (e.g., Grey, 2005). In the Ura assemblage under discussion here, Appendisphaera envelopes make up some $20 \%$ of all acanthomorphs and about $10 \%$ of all well preserved microfossils. Another important acanthomorphic genus, comprising about $7 \%$ of all Ura microfossils, is Tanarium, here represented by three species: T. conoideum (Fig. 6.1, 6.2), T. tuberosum (Fig. 6.3) and the newly combined T. digitiformum (Fig. 7.6).

Three further taxa, Variomargosphaeridium litoschum (Fig. 6.4-6.6), Dicrospinasphaera virgata (Fig. 8), and Archaeotunisphaeridium aff. fimbriatum (Fig. 6.76.9) are spheroidal vesicles with hollow heteromorphic processes, known previously from 
occurrences in Australia (Grey, 2005). In contrast, ?Sinosphaera rupina (Fig. 7.2-7.4) exhibits similarities with populations from the Doushantuo Formation, China (Zhang et al., 1998), while Bullatosphaera vellata (Fig. 5.7) and Eotylotopalla strobilata (Fig. 9.1, 9.4) also occur in Ediacaran shales deposited along the margin of the East European platform (Vorob’eva et al., 2009a). Cavaspina cf. C. acuminata (Fig. 10.2) is a minor but distinctive component of the Ura microbiota, as are the previously (Nagovitsin et al., 2004) described taxa Cavaspina basiconica, Gyalosphaeridium minutum (Fig. 8.7), Eotylotopalla aff. delicata and Knollisphaeridium maximum (Fig. 8.5).

Acanthomorphic acritarchs have generally been interpreted as algal, and large ornamented Ediacaran acritarchs are no exception. The most general argument advanced in favor of this hypothesis is that extant algae, especially some dinoflagellates and green algae, form decay-resistant resting cell walls with symmetrically distributed processes. Of course, this argument is sufficient to interpret Ediacaran fossils only if the formation of decay-resistant acanthomorphic cysts is uniquely associated with algal life cycles. It isn't - both heterotrophic protists and animals in many different phyla form egg or diapause cysts when confronted with environmental conditions not conducive to growth, and many metazoan cysts resemble Ediacaran acritarchs (e.g., van Waveren and Marcus, 1993; Hill and Shepherd, 1997; Marcus and Boero, 1998; Cohen et al., 2009; see below).

Size constitutes a persistent difference between acanthomorphic resting cells of algae and animals. All known dinocysts and green algal zygospores have diameters less than 200 microns, and most are smaller than 100 microns across; in contrast, the egg and diapause cysts of animals often exceed 100 microns, and cyst diameters of 300-400 microns or more are common (compilation in Cohen et al., 2009). Observed differences find explanation in function: the size of algal cells is limited by diffusion (Beardall, 2009), whereas the large size of many animal resting eggs reflects metabolic provisioning for potentially long intervals of 
dormancy (Andrew and Herzig, 1984). Thus, the argument that large Ediacaran acanthomorphs are algal requires that one address the physiological question of why Ediacaran algal cells should have routinely reached sizes that their modern counterparts do not. [Phycomata of some prasinophyte green algae are larger, but within these walls, the metabolically active cytoplasm becomes limited to a thin layer adjacent to the phycoma wall (R. Kodner, personal demonstration); preserved cell contents in several Ediacaran acanthomorph taxa show that these cysts formed around unicells whose cytoplasm filled the cyst interior - evidence of cell division within cysts doubly eliminates dinoflagellates from consideration (Zhang et al., 1998; Yin et al., 2004; Yin et al., 2007; Yin et al., 2008).]

Arouri et al. (1999, 2000) advanced more specific arguments that several Ediacaran acritarchs from Australia represent algae, citing both ultrastructural and organic geochemical features of the fossils. In particular, Arouri et al. (1999) argued for the preservation of trilaminar sheath structure (TLS) in microfossil walls imaged using TEM. TLS is a very specific structure that consists of two thin electron dense laminae separated by an electron tenuous layer, the entire structure on the order of $10 \mathrm{~nm}$ thick (Allard and Templier, 2000; Hagen et al., 2002; Elias et al., 2010). TLS can be preserved in microfossils (Talyzina and Moczydłowska, 2000), but, as discussed by Willman and Moczydłowska (2007), this distinctive ultrastructure is not discernible in images of Ediacaran acanthomorphs published to date. Arouri et al. (2000) suggested that other Ediacaran acanthomorphs could be dinoflagellates, based in part on the absence of TLS, but the absence of such an ultrastructure characterizes many protistan and animal cysts.

Arouri et al. (1999) and Marshall et al. (2005) also reported the occurrence of aliphatic molecules comparable to algaenans in Ediacaran acanthomorphs. Some green algae do, in fact, synthesize algaenans, but so do unrelated protists, and increasing experimental and observational evidence suggests that at least some of the algaenans reported from Paleozoic rocks originated during diagenesis (Gupta et al., 2007, 2009; Kodner et al., 2009). 
Thus, while the observations of Arouri et al. and Marshall et al. do not rule out chlorophyte or other algal affinities for Ediacaran acanthomorphs, they do not provide strong evidence in support of such an attribution.

Details of morphology support the interpretation of many Ediacaran acanthomorphs as animal resting cells (Yin et al., 2007; Cohen et al., 2009). For example, ornamented egg cysts of the living copepod Acartia steueri resemble the Ediacaran genus Dicrospinasphaera (Onoue et al, 2004, fig. 4b), so much so that the modern structures, found as fossils, would probably be assigned to this Ediacaran genus. Similarly, egg cysts of the sea squirt Boltenia villosa (http://celldynamics.org/embryos/boltenia.html) bear close and specific similarity to Ediacaran genus Eotylotopalla; cysts of extant anostracans (Hill and Shepherd, 1997) closely resemble fossil species within the genus Tanarium; the extant fairy shrimp Brachinella longirostris can produce egg and diapause cysts much like Ediacaran Alicesphaeridium spp. (Cohen et al., 2009); and resting eggs of the extant branchiopod Eubranchipus vernalis are good and specific matches for egg cases surrounding phosphatized Ediacaran embryos in China (Xiao and Knoll, 2000). The anchor-like processes found in Ancorosphaeridium also bear broad comparison to hook-like processes on statoblasts of some freshwater bryozoa (Braehm, 1911), not to mention a few Devonian and younger plant spores (e.g., Wellman, 2002).

This is not to suggest that Ediacaran acanthomorphs can be assigned to specific phyla; nor do we wish to imply that all Ediacaran acanthomorphs have known matches among animal resting cysts. However, for Ediacaran acanthomorphs that do have close morphological analogs among extant organisms, the analogs tend to be animals. The hypothesis of animal affinity has an important practical consequence: it predicts a certain amount of taxonomic ambiguity, as observed in debates about the systematic paleontology of Ediacaran acanthomorphs (e.g., Grey, 2005). Modern animals commonly produce cysts that 
vary, sometimes strikingly, in morphology, depending on environmental conditions (e.g., Blades-Eckelbarger and Marcus, 1992).

Other taxa.-Sphaeromorph acritarchs occur throughout the Ura Formation, and are the most abundant specimens in most sampled horizons. Leiosphaeridia, the principal form genus for unornamented spheroidal acritarchs of broad stratigraphic range, is commonly interpreted as the phycomata of prasinophyte green algae (e.g., Tappan, 1980), and this may be the proper interpretation of many such fossils. Recently, however, TLS has been documented in some Cambrian and Proterozoic leiosphaerids (Talyzina and Moczydłlowska, 2000; Moczydłlowska, 2010; Moczydłlowska et al., 2010), indicating an affinity to chlorophycean greens. Also, a few leiosphaerids have wall ultrastructures seemingly unrelated to green algae (e.g., Javaux et al., 2004). Thus, while many Leiosphaeridia populations are reasonably interpreted as green algal, systematic confidence requires ultrastructural confirmation.

Some spheromorphic populations show evidence of distinctive excystment mechanisms. In particular, Schizofusa zangwenlongii (Fig. 9.8) consists of fusiform vesicles with median splits that essentially bisect the vesicle. In general aspect, these fossils resemble Leiosphaeridia; however, their mode of excystment is sufficiently distinctive to warrant the retention of Schizofusa as a separate genus (Grey, 2005). Other spheroidal vesicles contain dense organic bodies in their interiors; generally assigned to the form taxon Aimia aff. A. gigantica (Fig. 9.7), they have previously been reported mainly from pre-Ediacaran strata (Hermann, 1979). The systematic affinities of these microfossils are obscure.

Filamentous microfossils form a low diversity component of microfossil assemblages throughout the Ura Formation. Probable cyanobacteria include cylindrical sheaths assigned to Siphonophycus spp. (Fig. 10.10), reminiscent of sheaths secreted by the so-called LPP (Lyngbya/Phormidium/Plectonema) cyanobacteria along the margins of present day oceans. Cyanobacteria-like sheaths are common throughout the Proterozoic Eon; they appear to have 
little biostratigraphic value. Other probable prokaryotes reported previously from Ura shales include helically coiled filaments (Fig. 10.9; Faizullin, 1998, pl. 3, fig. 5); Polytrichoides lineatus, bundles of filamentous sheaths bound within a common cylindrical envelope (Faizullin, 1998, pl. 3, figs. 3, 4); and the akinete-like elongated bodies described by Faizulin (1998, pl. 3, figs. 10-14) as Digitus fulvus.

Rugosoopsis tenuis (Fig. 10.1, 10.3, 10.6) is the name given to non-branching tubes 50-90 $\mu \mathrm{m}$ in cross-sectional diameter that bear numerous cross ribs. The affinities of these fossils remain unclear; they could be large filamentous cyanobacteria or eukaryotic filaments. More securely interpreted as eukaryotic are large (35-65 $\mu \mathrm{m}$ in cross-sectional diameter) unbranched tubes with prominent dark rings, assigned to Segmentothallus aff. S. asperus (Fig. 10.4, 10.5)

Ceratophyton sp. (Fig. 10.7) is a conical structure up to $600 \mu \mathrm{m}$ long with parallel folds that at least broadly resemble Ceratophyton vernicosum, described from Lower Cambrian deposits (Volkova et al., 1979); these microfossils appear to be fragments of a larger structure, but what type of structure remains unresolved. Ellipsoidal vesicles with parallel folds assigned to cf. Cucumiforma sp. (Fig. 10.8) can be poorly preserved specimens of the genus Cucumiforma or compressed spherical vesicles of Leiosphaeridia.

Other populations found in our samples are treated informally because of low population size, poor preservation, or simple uncertainty in making a taxonomic assignment. For example, elongate fossils up to $150 \mu \mathrm{m}$ long with a neck-like opening at one end (unnamed form 2; Fig. 9.2, 9.3) superficially resemble vase-shaped fossils that are relatively widespread in ca. 800-750 Ma rocks (Porter and Knoll, 2000). At least some of the older fossils can be assigned to arcellid testate amoebae classified within the Amoebozoa (Porter et al., 2003), but to date, well preserved vase-shaped microfossils occur as petrifications, suggesting differences in original composition from the Ura fossils. On the other hand, the observed neck could be the truncated end of a cylindrical outgrowth. Other possible 
relationships include foraminifera (see, for example, Hua et al., 2010); also, the Ura fossils resemble, perhaps fortuitously, the egg cysts of some parasitic nematodes (e.g., Niblack et al., 2006). A number of additional species have been reported from the Ura Formation (Faizullin, 1998; Nagovitsin et al., 2004; Golubkova et al., 2010). We interpret many of them as diagenetic variants or junior synonyms of taxa described here; individual reports are discussed in the Systematic Paleontology section.

\section{MICROFOSSILS OF THE URA FORMATION: BIOSTRATIGRAPHY AND}

\section{PALEOBIOGEOGRAPHY}

The first complex acanthomorphic acritarchs discovered in the Ura succession were interpreted as Paleozoic, not an unreasonable conclusion at the time, as diverse acanthomorphs were not yet well known from pre-Paleozoic rocks (see Volkova, 1985, for a review). In this spirit, Pyatiletov (1983) suggested that the Ura remains were Ordovician microfossils “washed into” Proterozoic beds. Faizullin (1998) first demonstrated the indigenous nature of the Ura microfossils, correctly identifying most as taxa known from Pertatataka-type Ediacaran microfossil assemblages reported from other localities. However, in this and in a subsequent paper (Nagovitsin et al., 2004), some forms were mistakenly assigned to Tonian-Cryogenian taxa such as Trachyhystrichosphaera and Miroedichia. As a result the Ura assemblage was interpreted as Cryogenian (late Late Riphean) in age, and the entire Dalnyaya Taiga Group was assigned to the Baikalian, nominated as a Regional Stage of the Siberian Platform (Faizullin, 1998; Nagovitsin et al., 2004).

As interpreted here (see also Vorob’eva et al., 2008; Sergeev et al, 2010; Golubkova et al., 2010), the exceptionally-preserved Ura microbiota shares multiple distinctive species with Ediacaran assemblages of the Pertatataka type, or ECAP. Diverse acanthomorphic acritarchs assigned to species of Tanarium, Cavaspina, Appendisphaera, Dicrospinasphaera, 
Variomargosphaeridium, and Sinosphaera occur not only in Ura shales but also in the Pertatataka Formation (Central Australia), Doushantuo Formation (southern China), Infrakrol Formation (Lesser Himalayas), Vychegda Formation (Kel'tma microbiota, the northeastern passive margin of the East European Platform), Scotia Group (Spitsbergen), and upper part of the Nepian Horizon (central part of the Siberian Platform; see Sergeev et al., 2010, for review). The time distribution of these assemblages is largely bracketed between the Acraman Impact Event in Australia at about 570 Ma (Grey, 2005) and the base of the East European Platform Redkino Regional Stage dated at 558 \pm 1 Ma (Martin et al., 2000; Grazhdankin, 2003). Nonetheless, the observation that large acanthomorphic acritarchs appear in low numbers just above post-glacial rocks dated at $632 \mathrm{Ma}$ in China (Zhou et al., 2007; Yin et al., 2007; McFadden et al., 2006, 2008) indicates that such microfossils could provide a biostratigraphic basis for recognizing the lower boundary of the Ediacaran Period.

Grey (2005; see also Grey and Calver, 2007) recognized four assemblage zones in the ECAP, demonstrating a potential for high resolution biostratigraphic correlation, but until now these zones have not been confirmed from other basins. The Ura association comprises abundant representatives of the genera Tanarium, Schizofusa, Variomargosphaeridium, Appendisphaera, Dicrospinasphaera, and the newly described Ancorosphaeridium, corresponding most closely with Grey’s second (Tc/Sr/Vl - Tanarium conoideum/ Schizofusa risoria/ Variomargosphaeridium litoschum) assemblage zone. Golubkova et al. (2010) reported from the Ura assemblage Multifronsphaeridium pelorium, a key taxon for Grey’s third assemblage zone (Ti/Cg/Mp - Tanarium irregulare/ Ceratosphaeridium glaberosum/ Multifronsphaeridium pelorium); however, our reinvestigation suggests that this population is better placed within another originally Australian taxon, Dicrospinasphaera virgata (see Systematic Section). International biostratigraphic subdivision of the ECAP biota remains a work in progress; however, despite fine-scale uncertainties, Ura acritarchs unambiguously place this formation within the lower to middle Ediacaran (Vendian). Microfossils, thus, 
corroborate chemostratigraphic data (Pokrovskii et al., 2006), resolving questions of BaikalPatom stratigraphy under debate for more than thirty years.

Interpretation of the Dalnyaya Taiga Group as early Ediacaran dramatically changes the tectonic model of the Baikal-Patom folded area (the Ura, Patom-Zhuya and adjacent structural-facies zones) as well as the southern passive margin of the Siberian Platform. The Meso-Neoproterozoic (Riphean) sedimentary succession of the Siberian platform was early on subdivided into a series of Regional Stratigraphic units considered as the types for potentially global biostratigraphic subdivisions of the later Proterozoic Eon: the Uiaian, Aimchanian, Mayanian (Kerpylian and Lakhandinian), and Baikalian (Khomentovsky et al., 2008). The Patom Supergroup was chosen as a type section for the Baikalian, embracing rocks estimated to be ca. 850-635 Ma (or 650 Ma, as accepted in the Russian Stratigraphic Scale as the lower boundary of Vendian System). Together, chemostratigraphy and Ura microfossils reframe the time available for Baikalian tectonic events.

The new correlations suggest that the lower boundary of Ediacaran system should be placed regionally about a kilometer below the Ura Formation, at the base of the Barakun Formation cap dolomites that lie directly above Bolshoi Patom diamictites. This is consistent with stratigraphic data from Australia, where ECAP acritarch assemblages appear as much as several hundred meters above Marinoan tillites (Grey, 2005), separated from them by an interval of low diversity acritarchs called the Ediacaran Leiosphere Palynoflora. Similarly, in China, diverse acanthomorphic acritarchs of the Doushantuo Formation are preceded by assemblages dominated by simpler and less diverse microfossils, with only rare acanthomorphs (Yin et al., 2007; Zhou et al., 2007; McFadden et al., 2006, 2008). On the passive margin of the East European Platform, the upper Vychegda Formation contains ECAP (the Kel'tma microbiota) and is separated from a lower Vychegda assemblage containing Cryogenian acanthomorphic acritarch taxa by an assemblage dominated by simple filaments and spheroidal microfossils (Vorob'eva et al, 2009a,b). The most parsimonious 
interpretation is that the base of the Ediacaran System lies near the boundary between the lower and middle Vychegda microfossil assemblages. Therefore, an expanding global database suggests that basal Ediacaran assemblages are characterized by long-ranging and morphologically simple taxa, mainly species of Leiosphaeridia. Following this, diverse assemblages of distinctively large and ornamented acritarchs formed in basins distributed on several continents, providing a reliable indication of pre-Redkino Ediacaran age.

Biogeographic distribution of ECAP acritarch taxa.-Within Russia, Ediacaran acanthomorph assemblages have been reported from the northeastern margin of the East European Platform, the Ura Formation, near the Lena River in southeastern Siberia, and half a dozen localities between these geographic extremes (Sergeev et al., 2010; Golubkova et al., 2010). Relying on the best documented assemblage from central Siberia, that of the Khamaka Formation (Moczydłowska et al., 1993; Moczydłowska, 2005), we can quantify similarities across Russia using Sorensen’s Quotient of Similarity $(Q / S=100 \times 2 j /(a+b)$, where $\mathrm{a}$ and $\mathrm{b}$ are the number of taxa found in each assemblage and $\mathrm{j}$ equals the number of taxa in both assemblages; Vorob'eva et al., 2009a). In their discussion of the Ediacaran acanthomorph assemblage from the Vychegda Formation, northeastern Russia, Vorob’eva and coauthors found its composition to be more similar to that of the Khamaka assemblage than it was to contemporaneous assemblages from Australia or China. At the genus level, the pair-wise similarity of the Ura assemblage to those of the Vychegda and Khamaka assemblages is a bit lower than that previously calculated for the Vychedga-Khamaka comparison (Q/S=50 for Vychegda/Khamaka, 40 for Ura-Khamaka, and 38.5 for Ura/Vychedga). As expected, species-level comparisons show lower similarity (Q/S=27.5 for Ura-Khamaka and 23.3 for Ura/Vychedga).

These pair-wise comparisons indicate that Ediacaran acanthomorph assemblages are less similar to one another than are widely distributed Cambrian acritarch assemblages from a common biostratigraphic zone (Vorob’eva et al., 2009a). The relatively low similarity of 
Ediacaran acanthomorph assemblages across the present day Russian land mass could reflect age, environment or biogeographic provinciality. At present, none of these factors can be ruled out, although a pair-wise comparison of Australian assemblages in Grey’s (2005) biostratigraphic zones 2 and 3 shows a higher level of similarity $(\mathrm{Q} / \mathrm{S}$ for genera=66 and for species =73), suggesting that age per se may not explain observed differences. During the Ediacaran Period, the Vychegda assemblage lay on a different craton from that of the Ura and Khamaka assemblages, yet their pair-wise similarities are comparable. This leaves taphonomic or paleoenvironmental differences as potential drivers of assemblage differences, but to date we have only limited information the environmental settings of microfossil assemblages recovered from drill cores. In continuing research careful attention to issues of environment and biogeography may shed new light on the similarities and differences among Ediacaran acritarch assemblages and, thus, on the limits of biostratigraphic resolution likely to be achievable using these microfossils.

\section{CONCLUSIONS}

The systematic description of Pertatataka-like microfossils in Ura Formation corroborates chemostratigraphic data indicating an Ediacaran age for the Dalnyay Taiga Group. Indeed, Ura microfossils provide an unusually diverse and well preserved window on Ediacaran life. The Ura microbiota shares a number of morphospecies with other Ediacaran assemblages from the Siberian Platform, but also includes several distinctive taxa previously discovered along the margin of the East European Platform. Globally, ECAP microfossil assemblages share enough taxa to facilitate biostratigraphic correlation, but have enough distinctive species to encourage continuing analyses of both facies and biogeographic distribution. In the long run, Ediacaran acanthomorphs promise to provide tools that will help resolve patterns of Ediacaran sediment accumulation in both time and space. 


\section{SYSTEMATIC PALEONTOLOGY}

Where appropriate, taxonomic descriptions indicate the mean diameter, or for cylindrical fossils, mean cross-sectional diameter $(\mathrm{x})$, standard deviation $(\sigma)$, coefficient of variation $(\mathrm{V}$, where $\mathrm{V}=[\sigma / \mathrm{x}] \times[100 \%])$, and number of measured specimens (n) on which these statistical data are based.

Location of specimens within maceration slides.-Figure legends identify the slide containing the fossil in question, the horizon from which the sample was obtained, the location of the specimen within the fossiliferous maceration slide (denoted by a number, the point and thin section-specific specimen number denoted on an overlay-map attached to the maceration slide, and by the England Finder Slide coordinate of the specimen), and the catalogue number of that specimen in the GIN paleontological collection. Thus, for the specimen of Bullatosphaera velata shown in Fig. 4.4, the relevant information-2-2005-914-4, O54[0], GINPC 14701-243—indicates that the illustrated fossil occurs in maceration slide 2-2005-9 prepared from a rock sample of the Ura Formation obtained from horizon 14 (shown in Fig. 2b); that within this maceration slide, the fossil occurs at location point 4 and within the England Finder Slide central circled O54 area; and that the specimen, itself, is catalogued as GINPC 14701-243.

Group ACRITARCHA Evitt, 1963

ACANTHOMORPH ACRITARCHS

Genus ANCOROSPHAERIDIUM new genus

Type species.-Ancorosphaeridium magnum new species.

Other species.-Ancorosphaeridium minor new species. 
Diagnosis.—Spheroidal or irregular vesicles bearing a moderate number of long hollow processes separated from vesicle interior. Processes long, slender, cylindrical, expanding toward base and tapering to a distal termination marked by anchor-like tips. Processes may occur on only one hemisphere of vesicle.

Etymology.-From the Greek ancora, meaning anchor, and sphaeridium, meaning ball or sphere, with reference to fossil shape.

Discussion.-Like the established genera Appendisphaera, Tanarium and Ericiasphaera, Ancorosphaeridium is characterized by an abundance of long hollow processes. The new genus differs from other genera, however, by its anchor-like process terminations. Earlier described microfossils from Australia (e.g., Willman et al., 2006, p.31, and Zang et al. (1992, figs. 19B, 42G-42I, 43A-43D) show possible blunt branches at process terminations, but neither light photographs nor SEM images convincingly illustratee grapnel hook-like morphology of Ancorosphaeridium.

\section{ANCOROSPHAERIDIUM MAGNUM new species}

Figures 4.1, 4.2, 4.2a, 4.3, 4.3a, 7.1, 7.1b

Envelope with processes of different shapes, VoroB'EVA, SERGEEV, AND CHumaKov, 2008, fig. $2 \mathrm{~m}-20$.

Envelope having transparent processes with hook-like ends, VOROB’EVA, SERGEEV, AND CHumakov, 2008, fig. 2d, 2e.

Diagnosis.—A species of Ancorosphaeridium with spheroidal or irregular vesicles up to $325 \mu \mathrm{m}$ in diameter bearing processes 5-27 $\mu \mathrm{m}$ wide and up to $180 \mu \mathrm{m}$ long with large anchorlike closed or open tips.

Description.--Translucent or opaque spheroidal, sub-spheroidal or irregular vesicles bearing thin, cylindrical, hollow, processes terminating with anchor-like or hook-like tips. 
Processes separated from vesicle interior, heteromomorphic, either evenly distributed over vesicles surface or located to one side only. Every process expands and divides near tip into four to eight segments resembling grapnel hooks. Process tips normally open with dehiscent segments or closed, and commonly broken. Vesicle dimensions 130 x $180 \mu \mathrm{m}$ to 270 x 380 $\mu \mathrm{m}$ (mean diameter $=232 \mu \mathrm{m}, \sigma=57 \mu \mathrm{m}, \mathrm{V}=24 \%$, $\mathrm{n}=9$ ); process length (if unbroken) $30-180$ $\mu \mathrm{m}(\mathrm{x}=125 \mu \mathrm{m} ; \sigma=40 \mu \mathrm{m}, \mathrm{V}=32 \%, \mathrm{n}=26)$; process width 5-27 $\mu \mathrm{m}(\mathrm{x}=11 \mu \mathrm{m}, \sigma=4 \mu \mathrm{m}$, $V=35 \%, n=56$ ); ratio of process length to vesicle diameter $1 / 5$ to $1 / 2$; length of processes expansion near tips 8-28 $\mu \mathrm{m}(\mathrm{x}=13 \mu \mathrm{m}, \mathrm{n}=30)$; anchor-like tip segments length 9-29 $\mu \mathrm{m}$ $(\mathrm{x}=15 \mu \mathrm{m}, \mathrm{n}=40)$; number of segments per tip 4-8.

Etymology.-From the Latin magnum, meaning large, with reference to the much smaller size of processes in the second species of this newly established genus.

Type.-Figure 4.3, 4.3a, specimen 2-2005-12-3-2, No. 14701-483; early Ediacaran, the Ura Formation.

Material examined.-Twenty-two fully preserved specimens from the Ura Formation.

Occurrence.-The Ura River, left tributary of the Lena River 5.5 km upstream from its mouth or $15 \mathrm{~km}$ upstream from Chapaevo settlement.

Discussion.-Ancorosphaeridium magnum and Ancorosphaeridium minor differ markedly in process size, facilitating their differentiation.

\section{ANCOROSPHAERIDIUM MINOR new species}

Figure 4.4, 4.4a, 4.5

Diagnosis.—A species of Ancorosphaeridium with ellipsoidal or irregular vesicles up to $210 \mu \mathrm{m}$ wide, bearing processes $0.5-14 \mu \mathrm{m}$ wide and up to $27 \mu \mathrm{m}$ long with small anchor-like tips. 
Description.-Translucent or opaque ellipsoidal, sub-spheroidal or irregular vesicles bearing thin, cylindrical, hollow processes terminating in anchor-like tips. Processes separated from vesicle interior, heteromomorphic, splitting near tips into four to five segments resembling petals with sharp ends. Process tips normally open with dehiscent segments or closed, but commonly broken. Vesicle dimensions 150 x $200 \mu \mathrm{m}$ to 70 x210 $\mu$ m (mean diameter $=192 \mu \mathrm{m}, \mathrm{n}=2)$; process length $13-27 \mu \mathrm{m}(\mathrm{x}=19 \mu \mathrm{m}, \sigma=4 \mu \mathrm{m}, \mathrm{V}=20 \%, \mathrm{n}=9)$; process width mostly around $0.5 \mu \mathrm{m}$, but can expand to $14 \mu \mathrm{m}$ near base; ratio of process length to vesicle diameter $1 / 15$ to $1 / 6$; anchor-like tip segments width 0.5 to $2-3 \mu$ m near base; number of segments per tip normally 4.

Etymology.-From the Latin minor, meaning small, with reference the relatively small processes of this species compared to the second described species of Ancorosphaeridium.

Type: Figure 4.4, 4.4a, specimen 2-2005-11-9-3, No. 14701-363; early Ediacaran, the Ura Formation.

Material examined.-Four well preserved specimens from the Ura Formation.

Occurrence.-The Ura River, the left tributary of the Lena River 5.5 km upstream from its mouth or $15 \mathrm{~km}$ upstream from Chapaevo settlement.

Discussion.- Ancorosphaeridium minor bears thin, cylindrical, hollow processes that terminate in anchor-like tips. Some previously described forms from the Ediacaran Pertatataka assemblage of Australia appear to have at least superficially similar processes, e.g., Alicesphaeridium medusoideum (Amadeusphaeridium spatiosum in original description) (Zang) in Zang and Walter, 1992, emend. Grey, 2005 (Zang and Walter, 1992, fig. 19B, 19D, 19F). However, Alicesphaeridium species have highly variable processes (Vorob’eva et al., 2009a), and neither this taxon nor any other previously reported form combines the process morphology and overall from exhibited by A. minor.

Genus ApPendisphaERA Moczydłowska, Vidal, and Rudavskaya, 1993, emend. Moczydłowska, 2005, emend. Grey, 2005 
Type species.-Appendisphaera grandis Moczydłowska, Vidal, and Rudavskaya, 1993

APPENDISPHAERA TENUIS Moczydłowska, Vidal, and Rudavskaya, 1993, emend. Moczydłowska, 2005

Figure 5.4, 5.4b, 5.5, 5.5a, 5.6, 5.6a

Appendisphaera tenuis MoczydŁowsKA, VIDAL AND RudAVsKaYA, 1993, p. 506-508, textfig. 7; MocZYDŁOWSKA, 2005, p. 296-298, fig. 5A-5F; GREY, 2005, p. 224-226, fig. 113A-113D; Yin, ZHU, KNOLL, YUAN, ZHANG AND Hu, 2007, p. 661, fig. 1b;

GolubKova And RAEVSKaya, 2007, pl. 1, fig. 4; VoroB’EVA, SERgEeV AND

CHUMAKOV, 2008, fig. 2k, 2l; WiLLMAN AND MocZYDŁOWSKA, 2008, p. 520, 521, figs. 7B, 7C, 8A, 8B.

(Part) Ericiasphaera aff. A. addspersa GREY, 2005. GOLUBKOVA, RAEVSKAYA, AND KuZNETSOv, 2010, pl. 4, fig. 6a, 6b.

Description.-Translucent spherical or subspherical vesicles bearing numerous closely and evenly spaced hair-like processes. Processes flexible, widening slightly toward base and tapering toward acute tips. Processes separated from vesicle interior, homomorphic, more or less of the same length, unbranched and so thin that it is difficult to determine are they solid or hollow. Vesicles bear numerous folds, but widely opening vesicles are not observed. Vesicle walls hyaline to finely granular; surface smooth. esicle dimensions 165 x $165 \mu \mathrm{m}$ to 260x330 $\mu \mathrm{m}$ (mean diameter $=245 \mu \mathrm{m}, \sigma=34 \mu \mathrm{m}, \mathrm{V}=14 \%, \mathrm{n}=16$ ) process length $7-12 \mu \mathrm{m}$ ( $\mathrm{x}=9 \mu \mathrm{m}, \sigma=2 \mu \mathrm{m}, \mathrm{V}=20 \%, \mathrm{n}=100)$; process width $1-2 \mu \mathrm{m}$ to $4 \mu \mathrm{m}$ near bases $(\mathrm{x}=2.5 \mu \mathrm{m}$, $\sigma=1 \mu \mathrm{m}, \mathrm{V}=36 \%, \mathrm{n}=100$ ); ratio of process length to vesicle diameter $1 / 20$ to $1 / 25$.

Material examined.-Around forty well-preserved vesicles.

Occurrence.-Early Ediacaran: Khamaka, Kursov and Ura formations, Siberia; Doushantuo Formation, China; Pertatataka and Tanana Formations, Australia. 
Discussion.-The Ura population clearly falls within the genus Appendisphaera. Process length is short relatively to previously described populations of $A$. tenuis, but is judged to lie within the limits of the species.

\section{APPENDISPHAERA SP.}

Figure 5.1, 5.2, 5.2a, 5.3

Description.--Translucent spherical or ellipsoidal vesicles bearing irregularly and sparse spine-like processes, often located to one side or central part of vesicle only. Processes hollow, slender, cylindrical or conical, tapering toward apices to sharp or broken ends; each process extends from one base only, or bases are unclear. Vesicle walls hyaline; surface smooth or finely-granular. esicle dimensions diameter 130 x $175 \mu \mathrm{m}$ to 200 x $225 \mu \mathrm{m}$ (mean diameter $=190 \mu \mathrm{m}, \sigma=20 \mu \mathrm{m}, \mathrm{V}=9.5 \%, \mathrm{n}=14)$, process length $1-8 \mu \mathrm{m}(\mathrm{x}=3 \mu \mathrm{m}, \sigma=2.3 \mu \mathrm{m}$, $V=75 \%, n=100$ ), width $0.5 \mu \mathrm{m}$ to $4 \mu \mathrm{m}$ near bases ( $\mathrm{x}=1 \mu \mathrm{m}, \sigma=1 \mu \mathrm{m}, \mathrm{V}=100 \%, \mathrm{n}=100)$; ratio of process length to vesicle diameter $1 / 200$ to $1 / 20$. Vesicles often split into unequal halves or thirds 50-95 $\mu \mathrm{m}$ wide $(\mathrm{x}=70 \mu \mathrm{m})$ and 25-110 $\mu \mathrm{m}$ long $(\mathrm{x}=50 \mu \mathrm{m}) ; 70-90 \mu \mathrm{m}$ spheroidal bodies may be present in vesicle interiors.

Material examined.-Around ninety well-preserved vesicles.

Genus ArChaEOTUnisPhaERIDIUM Grey, 2005

Type species.—Archaeotunisphaeridium fimbriatum Grey, 2005

ARCHAEOTUNISPHAERIDIUM AFF. FIMBRIATUM Grey, 2005

Figure 6.7, 6.8, 6.8a, 6.9

Archaeotunisphaeridium fimbriatum GREY, 2005, p. 229, figs. 119A-119D, 120A-120G. 
(Part) Simia simica (YANKAUSKAS, 1980). FAIZULLin, 1998, pl. 1, figs. 17-19.

Form 3. NAGOVITSIN, FAizULlin, AND YAKSCHIN, 2004, p. 14, pl. 1, figs. 8, 9.

Description.—Vesicles opaque, spheroidal to ellipsoidal or irregular, bearing a moderate number of discrete but poorly preserved processes distributed over the vesicle surface. Processes hollow, arise directly from vesicle walls, heteromorphic: unbranched, bifurcating or repeatedly branching, with slightly expanding fringe-like terminations. Processes partially or completely surrounded by translucent outer membrane. Processes and membrane walls fine- to medium-grained; outer membrane surface texture medium-grained. Vesicle diameter ranges from 150 to220 $\mu \mathrm{m}(\mathrm{x}=190 \mu \mathrm{m}, \sigma=23 \mu \mathrm{m}, \mathrm{V}=12 \%, \mathrm{n}=10)$; process length 15-50 $\mu \mathrm{m}(\mathrm{x}=24 \mu \mathrm{m}, \sigma=14 \mu \mathrm{m}, \mathrm{V}=57 \%, \mathrm{n}=10)$; process width 25 to $65 \mu \mathrm{m}$ near bases $(\mathrm{x}=30 \mu \mathrm{m}, \sigma=10 \mu \mathrm{m}, \mathrm{V}=35 \%, \mathrm{n}=23)$.

Material examined.-Fourteen poorly-preserved vesicles.

Occurrence.—Early Ediacaran: Ura Formation, Siberia; Tanana Formation, South Australia.

Genus Bullatosphaera Vorob’eva, Sergeev and Knoll, 2009 Type species.—Bullatosphaera velata Vorob’eva, Sergeev and Knoll, 2009.

BullatosPhaERA Velata Vorob’eva, Sergeev and Knoll, 2009

Figure 5.7, 5.7a

Envelopes with tubercular-like processes, VoroB'EVA, SERGEEV, AND SEMIKHATOV, 2006, fig. $2 h$.

Bullatosphaera velata VOROB’EVA, SERGEEV AND KNOLL, 2009a, p. 177, fig. 12.8-12.8c; SERGEeV, Semikhatov, Fedonkin And Vorob’EVA, 2010, pl. 2, fig. 13. 
Description.--Spheroidal to ellipsoidal double-walled vesicles bearing numerous small spheroidal or bulbous structures evenly distributed over inner vesicle surface or between inner and outer wall layers. Small structures subspherical or sometimes rectangular due to compression, nested in pits on the external surface of inner vesicle layer and draped by the outer layer. Vesicle walls hyaline; surface smooth or finely-granular. Vesicle dimensions 250 x 300 $\mu \mathrm{m}$ to $280 \mathrm{x} 400 \mu \mathrm{m}$ (mean diameter $=340 \mu \mathrm{m}$ ), with small spheroidal or subspherical structures $20-45 \mu \mathrm{m}$ in diameter. Vesicle inner layer translucent to nearly opaque, fine-grained, with folds $2-5 \mu \mathrm{m}$ thick; outer layer nearly transparent, hyaline, less than $0.5 \mu \mathrm{m}$ thick.

Material examined.-Two nearly complete specimens.

Occurrence._Early Ediacaran: Ura Formation, Siberia; Vychegda Formation, Timan Uplift, East European Platform.

Remarks.-The Ura microfossils are closely similar in size and morphology to the type specimen from the Vychegda Formation. The nature of the small surface spheroids nonetheless remains uncertain. Either they are bulbiform processes closed proximally, or they are bud-like structures that arise from the inner vesicle. Because of this uncertainty, the biological interpretation of these large, complex acritarchs remains unknown.

Genus CAVAsPina Moczydłowska, Vidal, and Rudavskaya, 1993

Type species.-Cavaspina acuminata (Kolosova, 1991) emend. Moczydłowska, Vidal, and Rudavskaya, 1993.

Cavaspina CF. C. ACuminata (Kolosova, 1991), emend. Moczydłowska, Vidal, and Rudavskaya, 1993

Figure 10.2 
(Part) Baltisphaeridium pilosiusculum YANKAUSKAS in VOLKOVA, KIRJANOV, PISKUN, PASKEVICIEN,E AND YANKAUSKAS, 1979. RudAVSKAYA AND VASIL’EVA, 1989, pl. 2, figs. 4-6.

Baltisphaeridium sp. RUDAVSKAYA AND VASIL’EVA, 1989, pl. 2, fig. 7.

Unnamed specimen, RudAVSKAYA AND VASIL’EVA, 1989, pl. 1, fig. 5.

Baltisphaeridium (?) acuminatum Kolosova, 1991, p. 57, 58, fig. 4.1-4.3.

Cavaspina acuminata (KolOsova, 1991). MocZYDŁOWSKA, VIDAL, AND RUDAVSKAYA, 1993, p. 509, 510, text-fig. 10A, 10B; NAGOVITSIN, FAIZULLIN AND YAKSCHIN, 2004, p. 12, pl. 2, figs. 7, 8; MoczYDŁowsKA, 2005, p. 298, 299, fig. 6A, 6B; VeIs, VoroB’EVA, AND GolUBKOVA, 2006, pl. 1, figs. 5, 6, pl. 2, fig. 1, 1b; VoroB’EVA, SERGEEV AND KNOLL, 2007, pl. 1, fig. E; WILLMAN AND MocZYDŁOWSKA, 2008, p. 522, fig. 9C; VorOB’EVA, SERGEEV AND KNOLL, 2009a, p. 177, fig. 7.11.

Goniosphaeridium acuminatum (Kolosova, 1991). ZhAnG, Yin, XIAO, AND KNOLL, 1998, p. 28, 32, fig. 8.3 .

(Part) Cavaspina sp. VeIs, VoroB’EvA, AND GolubKovA, 2006, pl. 2, fig. 3, 3a.

Description.--Vesicles spheroidal to subspheroidal, subcircular in plan view, with rare compression folds. Vesicles bear a few blunt conical processes, moderate in number and length, distributed more or less randomly over the vesicle surface. Processes homomorphic, arising directly from the vesicle wall and remaining open to vesicle interior; processes hollow and cylindrical, slightly widened at base and tapering distally to a point, if not broken. Vesicle walls hyaline; surface smooth or finely-granular. Vesicle diameter 100-120 $\mu \mathrm{m}$; process length 5-7 $\mu \mathrm{m}$; process width from $1 \mu \mathrm{m}$ (near tip) to 3-5 $\mu \mathrm{m}$ (near base).

Material examined.-Three conjoined vesicles.

Occurrence._Early Ediacaran: Torgo, Ura, Turkut and Khamaka Formations, Siberia; Doushantuo Formation, China; Vychegda Formation, Timan Uplift, East European Platform; Tanana Formation, Australia. 
Discussion.-These Ura specimens are similar to Cavaspina acuminata, but poorly preserved processes make species attribution uncertian.

\section{Genus EotYlotopalla Yin, 1987}

Type species._Eotylotopalla delicata Yin, 1987

EOTYLOTOPALLA STROBILATA (Faizullin, 1998) now combination

Figure 9.1, 9.4, 9.4a

Lophosphaeridium strobilatum FAIZULLIN, 1998, p. 331, 332, pl. 1, figs. 4, 5.

Lophodiacrodium sp. NAGOVITSIN, FAIZULLIN, AND YAKSCHIN, 2004, p. 14, pl. 1, fig. 4.

(Part) Bavlinella faveolata SCHEPELEVA, 1962. Vorob’EVA, SERGEEV, AND SEMIKHATOV, 2006, fig. $2 \mathrm{w}$.

Eotylotopalla minorosphaera VOROB’EVA, SERGEEV AND KNOLL, 2009a, p. 178, fig. 9.11, 9.11b.

Description.—Spheroidal, single-walled vesicles 65 - $85 \mu \mathrm{m}$ in diameter, bearing numerous (>40 visible around periphery) hemispherical processes that open freely into vesicle interior. Vesicle wall translucent, fine-grained, less than $1 \mu \mathrm{m}$ thick; surface granular. Processes isometric, small, hemispherical, nearly equidimensional, $2-7 \mu \mathrm{m}(\mathrm{x}=5 \mu \mathrm{m})$ long, densely and evenly distributed over vesicle wall.

Material examined.-About a dozen specimens.

Occurrence._Early Ediacaran: Ura Formation, Siberia; Vychegda Formation, Timan Uplift, East European Platform.

Discussion.--This species was originally described from the Ura Formation as Lophosphaeridium strobilatum by Faizullin (1998), but illustrated by only a few small and unclear pictures. Vorob'eva et al. (2009a) subsequently described as new the taxon 
Eotylotopalla minorosphaera from the Vychegda Formation. Our studies of the Ura microbiota convince us that the Ura and Vychedga populations belong to the same species. According to the rules of Botanical nomenclature, this should be named as Lophosphaeridium strobilatum; however, the hemispherical processes observed on the surface of this form are clearly unlike the tubercles of Lophosphaeridium species, but similar to previously described species of Eotylotopalla. Therefore, we propose the new combination Eotylotopalla strobilata.

Three species of Eotylotopalla have been described from cherts of the Ediacaran Doushantuo Formation (E. dactylos and E. delicata), China (Zhang et al., 1998) and the shales of the Vychegda Formation (E. strobilata=minorosphaera), Timan uplift (Vorob'eva et al., 2009a) and the Ura Formation. Eotylotopalla strobilata differs from E. dactylos and E. delicata in its larger vesicle diameter and its smaller, but more numerous processes.

A vesicle of Eotylotopalla strobilata with spherical processes preserved on its polar sides only was compared by Nagovitsin et al. (2004) to the Paleozoic taxon Lophodiacrodium. We consider this feature as being of taphonomic origin and so include this specimen in our synonymy of Eotylotopalla strobilata.

Genus GyALOSPHAERIDIUM Zang, 1992, emend. Grey, 2005 Type species.—Gyalosphaeridium pulchrum Zang, 1992, in Zang and Walter, 1992 GYALOSPHAERIDIUM MINUTUM Nagovitsin and Faizullin, 2004 Figure 7.7

Gyalosphaeridium minutum NAGOVITSIN AND FAIZULLIN in NAGOVITSIN, FAIZULLIN, AND YAKSCHIN, 2004, p. 13, pl. 2, figs. 2, 3.

Goniosphaeridium urium NAGOVITSIN AND FAIZULLIN in NAGOVITSIN, FAIZULLIN, AND YAKSCHIN, 2004, p. 13, pl. 2, fig. 1. 
Description.--Vesicle subspheroidal in outline, with folds and ruptures. Vesicle bears numerous closely spaced, hollow processes that communicate freely with the vesicle cavity. Processes are predominantly cylindrical, with a slightly widened conical base, becoming straight and tapering toward the tips, heteromorphic to homomorphic. Vesicle walls hyaline; surface smooth or finely-granular. Vesicle $120-130 \mu \mathrm{m}$ in diameter; processes 8-10 $\mu \mathrm{m}$ long and 5-6 $\mu \mathrm{m}$ wide near widened bases.

Material.-One complete, but not well-preserved vesicle.

Discussion.-Generic distinctions among Ediacaran vesicles with hollow, weakly heteromorphic, but broadly conical processes remain a subject of debate, with specimens variously assigned to the genera Tanarium, Gyalosphaeridium, ?Sinosphaera, or ?Polygonium (see, for example, Grey, 2005). Grey (2005) points to the solid, filamentous tips of Gyalosphaeridium as diagnostic characters, and we follow this practice here, although such tip ends could originate during diagenesis. Nagovitsin and Faizullin (in Nagovitsin et al., 2004) described two closely similar species from Ura shales: Gyalosphaeridium minutum and Goniosphaeridium urium. We attribute one specimen in our material to G. minutum and consider $G$. urium to be its junior synonym. We also acknowledge previous opinions that Goniosphaeridium is not a valid taxon for Ediacaran acritarchs (Grey, 2005; Moczydłowska, 2005).

Occurrence.-Early Ediacaran: Ura Formation, Siberia.

Genus KnOLLiSPHAERIDIUM (Knoll, 1992), emend. Grey, 2005, nom. Willman and Moczydłowska, 2008

Type species.—Knollisphaeridium maximum (Yin, 1987), emend. Knoll, 1992, comb. Willman and Moczydłowska, 2008 
KNOLLISPHAERIDIUM MAXIMUM (Yin, 1987), emend. Knoll, 1992, comb. Willman and Moczydłowska, 2008

Figure 7.5, 7.5a

Baltisphaeridium sp. YIN, 1985 p. 239, pl. 4, figs. 5-8; YIN, 1986, p. 263, pl. 1, figs. 11, 12. Baltisphaeridium maximum YIN, 1987, p. 439-440, pl. 14, figs. 14, 15.

Echinosphaeridium maximum KNOLL, 1992, p. 765-766, pl. 5, figs. 5, 6; TIWARI AND

KNOLL, 1994, p. 198, pl. 1, fig. 3; ZhANG, Yin, XiAO AND KNOLL, 1998, p. 26, figs. 6.7-6.10, 7.1, 7.2.

Form 2. NAGOVITSIN, FAIZULLIN, AND YAKSCHIN, 2004, p. 14, pl. 2, fig. 6.

Knollisphaeridium maximum WILLMAN AND MocZYDŁOWSKA, 2008, p. 523, fig. 5E, 5F.

Description.--Vesicles spheroidal, subspheroidal, or irregular in outline, with folds common in compressed specimens. Vesicles bear numerous hollow, echinate processes that arise directly from vesicle wall. Processes open to vesicle interior, homomorphic, unbranched, with closed terminations, evenly and closely distributed over the vesicle surface. Vesicle walls hyaline to finely granular; surface smooth. Vesicle diameter 255-295 $\mu \mathrm{m}$; process length 1-3.5 $\mu \mathrm{m}$; process width $>0.5$ to 1.0-1.5 $\mu \mathrm{m}$ near bases.

Material examined.-Two complete and well-preserved vesicles.

Occurrence.—Early to mid Ediacaran: Ura Formation, Siberia; Doushantuo Formation, China; Scotia Group, Spitsbergen; Infrakrol Formation, Lesser Himalaya, India; lower Ungoolya Group, Dey Dey Mudstone and Tanana Formation, Australia.

Discussion.-Knoll (1992) proposed the genus Echinosphaeridium to encompass large echinate acritarchs found in Ediacaran beds; however, the name Echinosphaeridium had previously been used for a genus of extant chlorophytes (Lemmermann, 1904). For this reason, Willman and Moczydłowska (2008) erected the genus Knollisphaeridium for these distinctive microfossils. Its dense, hollow, echinate processes distinguish Knollisphaeridium 
from other genera. Vesicle diameter, process size and process morphology collectively distinguish Knollisphaeridium maximum from the two other species assigned to this genus: K. gravestockii Grey, 2005, comb. Willman and Moczydłowska, 2008 and K. triangulum (Zang), 1992 in Zang and Walter, 1992, comb. Grey, 2005, comb. Willman and Moczydłowska, 2008.

Genus DicrospinASPHAERA Yuan and Hofmann, 1998

Type species.—Dicrospinasphaera zhangii Yuan and Hofmann, 1998.

DICROSPINASPHAERA VIRGATA Grey, 2005

Figure 8.1, 8.1b, 8.2, 8.2a, 8.3, 8.4, 8.5, 8.5b

Dicrospinasphaera virgata Grey, 2005, p. 241-245, figs. 140A-140D, 141A-141E;

GolubKova, RaevsKaya, AND KuZNETSOv, 2010, pl. 4, fig. 8.

Dicrospinasphaera sp.: VoroB’EVA, SergeEv, AND CHUMAKOv, 2008, figs. 2c, 2j.

(Part) Multifronsphaeridium pelorium ZANG in ZANG AND WALTER, 1992. GOLUBKOVA, RAEVSKAYA, AND KuZNETSOV, 2010, pl. 4, fig. 9a, 9b.

Description._-Vesicles spheroidal, subspheroidal, or ellipsoidal in outline, with folds common in compressed specimens. Vesicles bear a moderate number of widely or closely spaced, heteromorphic, hollow processes that communicate freely with vesicle cavity. Processes high variable, commonly with complex, multiple or occasionally dichotomous branching. Process bases commonly broad, hemispherical to conical, developing either into short cylindrical structures that bifurcate repeatedly, or which branch directly from the basal structure. Vesicle walls hyaline to finely granular; surface finely-granular. Vesicle dimensions $120 \times 130 \mu \mathrm{m}$ to $155 \times 190 \mu \mathrm{m}$ (mean diameter=157 $\mu \mathrm{m}, \sigma=21 \mu \mathrm{m}, \mathrm{V}=13 \%, \mathrm{n}=8$ ); processes unequal in length, 10-30 $\mu \mathrm{m}$ long $(\mathrm{x}=19, \sigma=4 \mu \mathrm{m}, \mathrm{V}=23 \%, \mathrm{n}=27)$ and 5-30 $\mu \mathrm{m}$ wide near mound-like bases $(x=13 \mu \mathrm{m}, \sigma=6 \mu \mathrm{m}, \mathrm{V}=47 \%, \mathrm{n}=30)$. Length of branching parts of 
processes 7-18 $\mu \mathrm{m}(\mathrm{x}=12 \mu \mathrm{m}, \sigma=3 \mu \mathrm{m}, \mathrm{V}=25 \%, \mathrm{n}=30)$, width $2-12 \mu \mathrm{m}(\mathrm{x}=5.5 \mu \mathrm{m}, \sigma=2.7$ $\mu \mathrm{m}, \mathrm{V}=49 \%, \mathrm{n}=31)$; length of secondary branching parts of processes $3-11 \mu \mathrm{m}(\mathrm{x}=6 \mu \mathrm{m}$, $\sigma=2.1 \mu \mathrm{m}, \mathrm{V}=35 \%, \mathrm{n}=30)$.

Material examined.—Nine complete well-preserved vesicles.

Occurrence.—Early Ediacaran: Ura Formation, Siberia; Pertatataka Formation, Australia.

Discussion.—-Golubkova et al. (2010) identified some Ura specimens as Multifronsphaeridium pelorium, based on the presence of solid, multiply branching processes. Ura populations, however, differ from the type of $M$. pelorium in several important characters. For example, M. pelorium is usually irregular in shape, whereas $D$. virgata and $D$. zhangii vesicles are nearly circular in outline. Also, M. pelorium ranges up to $900 \mu \mathrm{m}$, whereas $D$. virgata vesicles are 120-330 $\mu \mathrm{m}$ across. Moreover, $M$. pelorium processes are 20-150 $\mu \mathrm{m}$ long, with only a few at the smaller end of this distribution and are extremely variable within a single specimen. In contrast, $D$. virgata processes are 20-60 $\mu \mathrm{m}$ and fairly uniform in length on a single specimen (Grey, 2005). The overlap in morphology between Multifronsphaeridium and Dicrospinasphaera has yet to be fully resolved; however, because the Ura population shows the vesicle morphology, size range and process morphologies diagnostic for Dicrospinasphaera, we assign these microfossils to D. virgata.

Genus SinOSPHAERA Zhang, Yin, Xiao, and Knoll, 1998 Type species.—Sinosphaera rupina Zhang, Yin, Xiao, and Knoll, 1998. ?SiNOSPHAERA RUPINA Zhang, Yin, Xiao and Knoll, 1998 Figure 7.2, 7.3, 7.4, 7.4a

Goniosphaeridium crebrum ZANG in ZANG AND WALTER, 1992, p. 54, fig. 40F-40J. 
Goniosphaeridium cf. crebrum ZANG in ZANG AND WALTER, 1992, fig. 39H, 39I.

Gyalosphaeridium kartoblastum ZANG in ZANG AND WALTER, 1992, p. 58, fig. 42A-42G.

Gyalosphaeridium sp. Gravestock, Morton And ZAng, 1997, p. 91, fig. G.

Sinosphaera rupina ZHANG, YIN, XIAO, AND KNOLL, 1998, p. 38, 40, fig. 11.4-11.10.

?Sinosphaera rupina ZHANG, Yin, XIAO AND KNOLL, 1998. GREY, 2005, p. 291, 292, fig.

201A-201D; Willman, MocZydŁowsKa AND GREy, 2006, p. 32, pl. 2, fig. 4;

WiLlMAN AND MoczydŁoWsKA, 2008, p. 526, fig. 11D-11F; VoROB’EVA, SERGEEV,

AND ChumaKov, 2008, fig. 2i; GolubKova, RAEvSKAya And KuZnetsov, 2010, pl.

4, fig. 5.

(Part) Meghystrichosphaeridium hadianensis ZHAnG, YIn, XIAO AND KnOLL, 1989.

Vorob’eVA, Sergeev, AND Chumakov, 2008, fig. 2b. (Pro. Err.).

Description.--Vesicles spheroidal or ellipsoidal (but not polygonal) in outline, with folds common in compressed specimens. Vesicles bear numerous hollow processes that arise directly from vesicle wall; processes cylindrical, tapering near the distal end to a conical tip. Processes open to vesicle interior, homomorphic, unbranched, and with closed terminations, evenly and closely distributed over the vesicle surface. Vesicle and process walls are translucent, fine-grained, about 1-2 $\mu$ m thick; wall also marked by conical invaginations 2-4 $\mu \mathrm{m}$ deep. Vesicle dimensions $105 \times 155 \mu \mathrm{m}$ to 140 x $160 \mu \mathrm{m}$; process length $10-26 \mu \mathrm{m}$ ( $x=16 \mu \mathrm{m}, \sigma=4 \mu \mathrm{m}, \mathrm{V}=23 \%, \mathrm{n}=27)$; process width 5-12 $\mu \mathrm{m}$ near bases $(\mathrm{x}=7 \mu \mathrm{m}, \sigma=2 \mu \mathrm{m}$, $V=25 \%, n=18$ ); ratio of process length to vesicle diameter ratio $1 / 5$ to $1 / 15$.

Material examined.-Three complete vesicles.

Occurrence.-Early Ediacaran: Pertatataka Formation, Australia; Ura Formation, Siberia; the Doushantuo Formation, China.

Discussion.-As discussed by Grey (2005) and Moczydłowska (2005), distinctions among Ediacaran acanthomorphs with hollow, conical processes can be difficult. Grey (2005) questionably assigned forms similar to those under consideration here to the genus 
Sinosphaera, uncertainty arising because small conical vesicle invaginations clearly visible in the type specimen from silicified carbonates of the Doushantuo Formation (Zhang et al., 1998) could not be discerned in Australian compressions. The Ura population presents a similar problem. We observed possible imaginations in Ura material, but followed Grey’s suggestion, classifying these fossils as ?Sinosphaera. Continuing research (e.g., Moczydłowska, 2005) may sort out lingering taxonomic issues; in any event, we consider that the described forms most similar to the Ura microfossils reported here are Grey's (2005) ?Sinosphaera rupina and, by extension, the type of Sinosphaera rupina from the Doushantuo Formation, China (Zhang et al., 1998).

Genus TANARIUM Kolosova, 1991, emend. Moczydłowska, Vidal and Rudavskaya, 1993, emend. Grey, 2005

Type species.-Tanarium conoideum Kolosova, 1991

TANARIUM CONOIDEUM Kolosova,1991, emend. Moczydłowska, Vidal and Rudavskaya, 1993

Figure 6.1, 6.2

(Part) Baltisphaeridium primarium YANKAUSKAS in VolKOVA, KIRJANOV, PISKUn, PaskeViciene, And YanKauskas, 1979. Pyatiletov, 1980, p. 11. pl. 1, figs. 1-4; Pyatiletov AND RUdAVSKAYA, 1985, p. 152. pl. 63, figs. 1-4; RUdAVSKAYA AND VASIL'EVA, 1989, pl. 1, fig. 7.

Tanarium conoideum Kolosova, 1991, p. 57, fig. 5.1-5.3; MoczydŁowSKA, VIDAL, AND RUDAVSKAYA, 1993, p. 514-516, text- fig. 10C, 10D; KNOLL, 1994, fig. 4G; FAIZULLIN, 1998, pl. 2, figs. 2-4, 8; GREY, 2005, p. 299-303, figs. 212A-212D, 213A-213D; MoczydŁowSKA, 2005, p. 302, 303, fig. 7A, 7C, 7E; WILLMAN, 
MoczydŁowsKa AND GREy, 2006, p. 32, pl. 6, figs. 1, 2; VoROB’EVA, SERGEEV AND KNOLL, 2007, pl. 1, fig. D; GolubKOva AND RAEVSKAYA, 2007, pl. 1, fig. 7; Willman AND MoczydŁowsKa, 2008, p. 526, 527, fig. 12C; Vorob’EVA, SERGEev, AND CHUMAKOV, 2008, fig. 2a; Vorob’EVA, SERGEEV, AND KNOLL, 2009a, p. 180, 182, fig. 7.4, 7.7; Vorob’EVA, SERGEeV, AND KNOLL, 2009b, fig. 4e; GolubKOVA, RAEvsKaya And KuZnetsov, 2010, pl. 3, fig. 7, pl. 4, fig. 2; SERGEev, Semikhatov, Fedonkin And Vorob’eva, 2010, pl. 2, figs. 9, 12. (Part) Hocosphaeridium scaberfacium ZANG in ZANG AND WALTER, 1992, p. 61, fig. 45A45E, 45G; ZANG in Gravestock, Morton, AND ZANG, 1997, p. 91, fig. E. Goniosphaeridium sp. A. ZANG in ZANG AND WALter, 1992, p. 54, fig. 45I, 45H. Goniosphaeridium conoideum (Kolosova, 1991). ZHANG, Yin, XIAO, AND KnOLL, 1998, p. 32, fig. 9.1-9.4

Tanarium sp.; VeIS, VoroB’Eva, AND GolubKovA, 2006, pl. 2, fig. 4; VoroB’EVA, SERGEeV, AND SEMIKHATOV, 2006, fig. 2s.

(Part) Cavaspina sp. VeIs, VoroB’EVA, AND GolubKOvA, 2006, pl. 1, fig. 7, pl. 2, fig. 5, 5 a. Description.--Vesicles spheroidal to ellipsoidal, circular to oval in plan view, with folds common in compressed specimens. Vesicles bear numerous discrete long processes distributed over the vesicle surface. Processes arise directly from vesicle walls; processes hollow and cylindrical to broadly conical, sometimes expanded near base. Processes open to vesicle interior, homomorphic or rarely heteromorphic, unbranched, with closed terminations. Vesicle walls hyaline; surface texture smooth. Vesicle dimensions 100-185 $\mu \mathrm{m}$ $(\mathrm{x}=160 \mu \mathrm{m}, \sigma=17 \mu \mathrm{m}, \mathrm{V}=10.5 \%, \mathrm{n}=18)$; process length $22-46 \mu \mathrm{m}(\mathrm{x}=36 \mu \mathrm{m}, \sigma=7 \mu \mathrm{m}$, $\mathrm{V}=19.5 \%, \mathrm{n}=19$ ); process width $3-7 \mu \mathrm{m}$ (near tips, $\mathrm{x}=5 \mu \mathrm{m}$ ) to $8-22 \mu \mathrm{m}$ (near mound-like bases, $x=12 \mu \mathrm{m})$. Process length $1 / 8-1 / 2$ of vesicle diameter; number of processes at equatorial margin 12-35 (mean 18).

Material examined.-Twenty five well-preserved vesicles. 
Occurrence._Early Ediacaran: Pertatataka and Tanana Formations, Australia; Kursov, Parsha and Ura Formations, Siberia; upper part of Vychegda Formation, East European Platform; Doushantuo Formation, China.

Discussion.-T. conoideum differs from other species of genus Tanarium by its conical and unbranched, basally broader, and irregularly distributed processes, but taphonomic alteration can lead to processes that appear deformed, truncated, or branched.

TANARIUM DIGITIFORMUM (Nagovitsin and Faizullin, 2004) new combination Figure 7.6

Goniosphaeridium digitiforme NAGOVITSIN AND FAIZULLIN in NAGOVITSIN, FAIZULLIN, AND YAKSCHIN, 2004, p. 13, pl. 2, figs. 4, 5.

“Goniosphaeridium” digitiforme NAGOVITSIN AND FAIZULLIN, 2004. GoLUBKOVA, RAEVSKAYA AND KuZNETSOV, 2010, pl. 4, fig. 3.

Description.--Vesicles translucent to opaque, spheroidal to ellipsoidal, circular to oval in plan view. Vesicles bear a moderate number of discrete broad processes irregularly distributed over the vesicle surface. Processes cylindrical or conical, arising directly from vesicle walls; hollow, homomorphic, unbranched, closed at the ends, terminating in sharp or blunt tips. Processes and vesicles walls medium to coarse-grained, about 2-3 $\mu$ m thick; vesicle surface texture coarse-grained to shagrinate. Vesicle diameter 110-120 $\mu$ m; process length 6.5-18 $\mu \mathrm{m}(\mathrm{x}=11.8 \mu \mathrm{m}, \sigma=3 \mu \mathrm{m}, \mathrm{V}=26 \%, \mathrm{n}=11)$; process width 3-8.5 $\mu \mathrm{m}(\mathrm{x}=6 \mu \mathrm{m}$, $\sigma=2 \mu \mathrm{m}, \mathrm{V}=30 \%, \mathrm{n}=11)$.

Material examined.-Two moderately well-preserved vesicles, one of which could be measured accurately.

Discussion.-This form was described as a new species of Goniosphaeridium, currently held to be invalid for Ediacaran acanthomorphic acritarchs (Grey, 2005). For this 
reason, these fossils are here transferred to the genus Tanarium (Kolosova, 1991;

Moczydłowska et al., 1993; Grey, 2005; Moczydłowska, 2005; Moczydłowska and Willman, 2008).

TANARIUM TUBEROSUM Moczydłowska, Vidal, and Rudavskaya, 1993

Figure 6.3

(Part) Baltisphaeridium primarium YANKAUSKAS in VOLKOVA, KIRJANOV, PISKUN,

PASKEVICIENE, AND YANKAUSKAS, 1979. RudAVSKAYA AND VASIL'EVA, 1989, p. 2, fig. 3.

Tanarium tuberosum MocZYDŁOWSKA, VIDAL, AND RUDAVSKAYA, 1993, p. 516-518, textfig. 15A-15D; MocZYDŁOWSKA, 2005, p. 303, 304, fig. 7B, 7D; WILLMAN, MoczydŁOWSKA AND GREY, 2006, p. 36, pl. 7, figs. 3, 4; GolubKOva AND

RAEVSKAYA, 2007, pl. 1, fig. 5; WILLMAN AND MOCZYDŁOWSKA, 2008, p. 527, 528,

fig. 12F; Vorob’EVA, SERGEEV, AND KNOLL, 2009a, p. 182, fig. 7.6, 7.8.

Ooidium sp. 1, FAIZULLIN, 1998, p. 332, pl. 1, fig. 12.

Tanarium triangulum FAIZULLIN, 1998, p. 332, 336, pl. 2, figs. 5, 6.

Tanarium sp. FAizUlLin, 1998, pl. 2, figs. 9-14.

Tanarium stellatum NAGOvitsin AND FAIZULlin in NAGOVITSIN, FAIZULLIN, AND YAKSCHIN, 2004, p. 14, pl. 2, figs. 16, 18.

Polygonium sp. NAgOvitsin, FAIZUldin, AND YAKSCHIN, 2004, p. 13, pl. 2, figs. 12-15.

Gen.et sp. indet. GolubKova, Raevskaya And Kuznetsov, 2010, pl. 4, fig. 4.

Non Asterocapsoides sinensis YiN AND Li, 1978. KNOLL, 1992, p. 762, 764, pl. 6, figs. 5, 6;

ZHANG, YIN, XIAO, AND KNOLL, 1998, p. 24, fig. 5.10.

Description.--Vesicles spheroidal to ellipsoidal, circular to oval in plan view, with folds common in compressed specimens. Vesicles bear a small number of discrete, bluntly 
conoidal processes distributed over the vesicle surface. Processes arise directly from vesicle wall and are conspicuously and broadly conical. Processes open to vesicle interior, homomorphic, unbranched, and with closed terminations. Vesicle walls hyaline to finely granular; surface smooth. Vesicle dimensions 145-270 $\mu \mathrm{m}$; process length (in longest dimension) $12-27 \mu \mathrm{m}$; process width $2-5 \mu \mathrm{m}$ (near tips) to 10-22 $\mu \mathrm{m}$ (near mound-like bases); processes length 1/15-1/6 of overall vesicle diameter; number of processes at equatorial margin 6-10.

Material examined.—Five well-preserved vesicles.

Occurrence.-Early Ediacaran: Kursov, Parsha and Ura Formations, Siberia; Vychegda Formation, East European Platform; lower Ungoolya Group, Dey Dey Mudstone and Tanana Formation, Australia.

Discussion.-The small number of conspicuously broad processes differentiates $T$. tuberosum from other species of the genus Tanarium. Other species of Tanarium and Polygonium sp. earlier described by Nagovitsin and Faizullin (Faizullin, 1998; Nagovitsin et al., 2004) fall within the range of variation observed elsewhere for this species.

Genus VARIOMARGOSPHAERIDIUM Zang, 1992

Type species._Variomargosphaeridium litoschum Zang, 1992

VARIOMARGOSPHAERIDIUM LITOSCHUM Zang, 1992

Figure 6.4-6.6

Variomargosphaeridium litoschum ZANG in ZANG AND WALTER, 1992, p. 114, 117, figs. 63D-63G, 88A-88H; GREY, 2005, p. 330, 331, fig. 257A-257F.

Variomargosphaeridium cf. V. litoschum ZANG in ZANG AND WALTER, 1992. VOROB’EVA, SERGEev, AND CHumaKov, 2008, fig. 2f, 2g. 
? Variomargosphaeridium litoschum ZANG in ZANG AND WALTER, 1992. GOLUBKOVA, RAEVSKAYA AND KuZNETSOV, 2010, pl. 4, fig. 7a, 7b.

Description.--Vesicles spheroidal to ellipsoidal, circular to oval in plan view, with folds common in compressed specimens. Vesicles bear a moderate number of discrete, cylindrical processes evenly distributed over the vesicle surface. Hollow processes arise directly from vesicle wall and open into vesicle interior, heteromorphic, simply to multiply branched, constricted and splitting near tip into many segments resembling paintbrush bristles. Vesicles translucent to opaque, walls medium- to coarse grained; surface chagrinate. Vesicle diameter 255-330 $\mu \mathrm{m}(\mathrm{x}=280 \mu \mathrm{m}, \sigma=39 \mu \mathrm{m}, \mathrm{V}=14 \%, \mathrm{n}=14)$; process length $30-100 \mu \mathrm{m}$ ( $\mathrm{x}=45 \mu \mathrm{m}, \sigma=12 \mu \mathrm{m}, \mathrm{V}=27 \%, \mathrm{n}=50)$ and width $7-20 \mu \mathrm{m}(\mathrm{x}=11 \mu \mathrm{m}, \sigma=8 \mu \mathrm{m}, \mathrm{V}=74 \%$, $\mathrm{n}=40)$; width of processes terminal constrictions $6-20 \mu \mathrm{m}(\mathrm{x}=9 \mu \mathrm{m}, \sigma=2 \mu \mathrm{m}, \mathrm{V}=27 \%, \mathrm{n}=50)$; width of terminal "paintbrush-like" segment bunches 12-30 (x=21 $\mu \mathrm{m}, \sigma=5 \mu \mathrm{m}, \mathrm{V}=22 \%$, $n=50$ ). Processes length $1 / 10-1 / 2.5$ of overall vesicle diameter; number of processes at equatorial margin 8-12.

Occurrence.—Early Ediacaran: Ura Formation, Siberia; Pertatataka Formation, Australia.

Material examined.-Sixty three completely and partially preserved vesicles.

Discussion.—Vorob’eva et al (2008) identified this form as Variomargosphaeridium cf. V. litoschum. Since then, many well preserved specimens have been found, removing any doubt about its formal taxonomic assignment.

\section{SPHEROMORPH AND NETROMORPH ACRITARCHS}

Genus Aimia Hermann, 1979

Type species.—Aimia delicata Hermann, 1979 
Figure 9.7

Aimia gigantica Hermann, 1979, p. 133, pl. 22, fig. 8.

Description.--Vesicles translucent, spheroidal to ellipsoidal, scattered in mucilage and surrounded by a large irregular common translucent envelope. Vesicles contain opaque dark spheroidal or irregular internal bodies about $1 \mu \mathrm{m}$ across. Vesicle wall medium-grained, surface texture coarse-grained to shagrinate; surrounding envelope wall fine-grained to hyaline, surface texture smooth. Vesicle diameter 6-16 $\mu \mathrm{m}$, vesicle walls 1-2 $\mu \mathrm{m}$ thick; outer envelope 100 x $260 \mu \mathrm{m}$ to 200 x $230 \mu \mathrm{m}$ and about $1 \mu \mathrm{m}$ thick.

Material examined.-A few hundred spheroids in four ensheathed colonies.

Discussion.-Aimia gigantica was described by Hermann (1979) from the late Mesoproterozoic Lakhanda Group of Siberia, and in some features like vesicle diameter, and the shape and dimensions of the outer envelope, the type is indistinguishable from the Ura population. However, in general, the shape of surrounding envelope in Ura population is irregular, in contrast to spherical and ellipsoidal colonies observed in the type Lakhanda assemblage (Hermann, 1979). For this reason, we described the Ura microfossils in open nomenclature.

Genus SCHIZOFUSA Yan, 1982

Type species.-Schizofusa sinica Yan, 1982.

SCHIZOFUSA ZANGWENLONGII Grey, 2005

Figure 9.8

Schizofusa sp. ZANG in ZANG AND WALTER, 1992, p. 96, fig. 71A-71H. not Schizofusa sp. ZANG in ZANG AND WALTER, 1992, p. 96, fig. 71I. 
Schizofusa zangwenlongii GREY, 2005, p. 191, figs. 71A-71D, 72A-72D.

Description.-Ellipsoidal fusiform vesicle, with a slit-like aperture along the longitudinal axis. Aperture bordered by thin, somewhat indistinct, narrow, more or less straight marginal ramparts or "lips” extended into short tapering terminations. Slits often gape differentially, being either closed at one end, or having a narrower opening at one end than at the other. Vesicles 210-350 $\mu \mathrm{m}$ long and 95-75 $\mu \mathrm{m}$ wide. Wall thick, translucent or opaque, corroded, laevigate or chagrinate, lacking processes, about 2-3 $\mu$ m thick.

Material examined.—Forty six well-preserved vesicles.

Occurrence.-Early Ediacaran: Pertatataka Formation, Australia; Ura Formation, Siberia; Doushantuo Formation, China.

FILAMENTOUS MICROFOSSILS

Genus Rugosoopsis Timofeev and Hermann, 1979

Type species._-Rugosoopsis tenuis Timofeev and Hermann, 1979

RugOSOOPSIS TENUIS Timofeev and Hermann, 1979

Figure 10.1, 10.3, 10.6

Rugosoopsis tenuis TIMOfEeV AND HERMAnN, 1979, p. 139, pl. 29, figs. 7, 5; YANKAUSKAS, 1989, p. 139, 140, pl. 29, fig. 3; MoczydŁowsKA, 2008, p. 82, fig. 9A (see MocZYDŁOWSKA, 2008 for complete synonymy). (Part). Botuobia patomica Kolosov, 1982. FAizullin, 1989, pl. 3, figs. 7-9.

Description.-Compressed, unbranched tubes containing numerous cross-ribs. Tubes 50-90 $\mu \mathrm{m}$ in cross-sectional diameter, up to $400 \mu \mathrm{m}$ long (incomplete specimen); tube wall translucent, medium-grained, 1-2 $\mu \mathrm{m}$ thick. Ribs opaque, 1-3 $\mu \mathrm{m}$ wide and 1-2 $\mu \mathrm{m}$ high; distance between ribs ranges from 5-7 to 8-10 $\mu \mathrm{m}$. 
Material.-Ten well preserved specimens.

Remarks.-Rugosoopsis tenuis is widely distributed in Proterozoic assemblages of carbonaceous compression microfossils, ranging from Calymmian (Early Riphean) to Ediacaran (Vendian).

Genus Segmentothallus Hermann, 1989

Type species.—Segmentothallus asperus Hermann, 1989

Segmentothallus AFF. S. ASPERUS Hermann, 1989

Figure 10.4, 10.5

Segmentothallus asperus HERMANN in YANKAUSKAS, 1989, p. 133, pl. 36, figs. 5-10;

HERMANN, 1990, pl. 16, figs. 1-9.

Description.-Cylindrical, compressed, unbranched tubes containing prominent dark rings separating filaments into segments slightly constricted between rings, septa indistinct. Tubes 35-65 $\mu \mathrm{m}$ in cross-sectional diameter, up to $390 \mu \mathrm{m}$ long (incomplete specimen); tube wall translucent, medium-grained, $\sim 2-3 \mu \mathrm{m}$ thick. Cross rings opaque, $4-8 \mu \mathrm{m}$ wide and 2-4 $\mu \mathrm{m}$ high; segments 50-150 $\mu \mathrm{m}$ long.

Material examined.-Six poorly to moderately well-preserved specimens.

Discussion.-Segmentothallus aff. S. asperus differs from type population of $S$. asperus (Lakhanda Group, Siberia) in having a smaller diameter. While this may be sufficient to erect a second species, but the poor preservation of Ura specimens urges caution in this respect. 
(Part) Palaeovaucheria clavata HeRmann, 1981. FAizullin, 1998, pl. 3, figs. 1, 2.

Palaeolyngbya sp. FAizULLin, 1998, pl. 3, fig. 15.

Oscillatoriopsis sp. FAIZULLIN, 1998, pl. 3, fig. 16.

Description.-Hollow, unbranched tubular fossils 10-20 $\mu \mathrm{m}$ in cross-sectional diameter, up to $500 \mu \mathrm{m}$ long (incomplete specimen); tube wound into a tight helix and refolded on itself; tube wall translucent to opaque, medium- to coarse-grained, $\sim 1-2 \mu$ m thick or thickness unclear. Material examined.--Some twenty variously preserved specimens.

Discussion.-We included in this informal taxon three species of filamentous microfossils earlier identified by Faizullin (1998) because they are not described and their illustrated images do not fit the formal diagnosis of the taxa to which they were assigned. The Ura microfossils resemble Obruchevella in their helical morphology, but differ from described Obruchevella species (Golovenok and Belova, 1983; Belova and Golovenok, 1999) in the tightness of their helices and refolded morphology. They also bear comparison to Heliconema, described from cherts of the ca. 800 Ma Bitter Springs Formation, Australia (Schopf, 1968; Schopf and Blacic, 1971). Heliconema specimens exhibit a tight helix, but whether their form represents a helical filament or the unraveling of a cylindrical tube with helical substructure (as in some extant cyanobacteria) remains uncertain. This is true of both the type species of the genus, H. australiensie (Schopf, 1968) and the type specimen of the subsequently described H. funiculum (Schopf and Blacic, 1971). Like Obruchevella and Heliconema, the Ura fossils could be helicoidal cyanobacteria, although other interpretations, both bacterial and eukaryotic, remain possible.

MisCELLANEOUS MICROFOSSILS 
Type species.—Ceratophyton vernicosum Kirjanov, 1979 in Volkova, Kirjanov, Piskun, Paskeviciene, and Yankauskas, 1979

\section{CERATOPHYTON SP.}

Figure 10.7

Description.-Fragmentary carbonaceous structures with a distinctly conical shape. Vesicle walls darkly translucent to opaque, with parallel folds, medium- to coarse-grained, broken at cone base and tip. Fragment is 150 x $600 \mu \mathrm{m}$; wall 1-3 $\mu \mathrm{m}$ thick.

Material examined.- One fragment.

Discussion.-Ceratophyton vernicosum was described from the Lower Cambrian Rovno and Lontova horizons (Regional Stages) of the East European Platform (Volkova et al., 1979). Subsequently, similar horn-like conical microfossils have been found in lower Ediacaran (Vendian) strata of the Vychegda Formation (Kel'tma microbiota), but described informally as unnamed form A despite having relatively large numbers of specimens (Vorob’eva et al., 2009a, p. 191, fig. 13.9, 13.10). Keeping in the mind that similarity of conical morphology can be superficial, we have elected to classify Ura and equivalent Kel’tma microfossils as Ceratophyton sp. The broken surfaces at cone bases indicate that these fossils are fragments of larger entities. To date, however, there is little sense of what the large entities may have been, nor whether these form taxa derive from more than one type of structure.

Genus CuCumiforma Mikhailova, 1986

Type species.-Cucumiforma vanavaria Mikhailova, 1986, emend Mikhailova in Yankauskas, 1989.

\section{CF. CUCUMIFORMA SP.}


Description.-_Solitary, single-layered ellipsoidal vesicles with rounded ends. Vesicle walls translucent, with numerous parallel folds that run along the major axis; walls mediumgrained, about $1 \mu \mathrm{m}$ thick. Ellipsoidal vesicles 230-300 $\mu \mathrm{m}$ long and 70-130 $\mu \mathrm{m}$ wide; length/width ratio $2-3$.

Material examined.-Fourteen poorly preserved specimens from.

Discussion.-The Ura microfossils differ from the type population of Cucumiforma vanavaria in their lack of clear parallel ribs stretching from one pole to the other. The folds observed in Ura specimens could be equivalent, although it is difficult to reject the alternative hypothesis that they arose during diagenesis. For this reason, they have been classified as cf. Cucumiforma sp.

\section{UNNAMED FORM 1}

Figure 10.11

Description.-Vesicles irregular with rarely preserved short processes, circular to oval in plan view, and with a neck-like extension arising from one surface; folds common in compressed specimens. Processes arise directly from vesicle walls; hollow and cylindrical to broadly conical, homomorphic, unbranched, with closed terminations, separated from vesicle interior. Vesicle walls medium-grained; surface texture shagrinate. Vesicle diameter 200-210 $\mu \mathrm{m}$; process length 3-4 $\mu \mathrm{m}$; process width $1-3 \mu \mathrm{m}$; neck-like attachment width $115 \mu \mathrm{m}$, length $75 \mu \mathrm{m}$.

Material examined.-Two poorly preserved vesicles, one of them measurable.

Discussion.-These vesicles are described informally because they are both rare and poorly preserved. The apparent spinose processes suggest a relationship to acanthomorphic acritarchs, especially Cavaspina acuminata; however, the neck-like extension suggests a 
different interpretation. Resolution awaits the discovery of more and better preserved specimens.

\section{UNNAMED FORM 2}

Figure 9.2, 9.2a, 9.3

Description.-Opaque vase-shaped vesicles, solitary or in planar tetrads, 105-150 $\mu \mathrm{m}$ in maximum and 65-90 $\mu \mathrm{m}$ in minimum dimensions, with a lobed aperture, 25-30 $\mu \mathrm{m}$ in diameter, at one end. Apertural margin consists of rounded outpocketings divided by inwardly directed points. Where visible, the vesicle surface is chagrinate and irregularly ruptured.

Material examined.- One tetrad and three single well-preserved vesicles.

Occurrence.-Ediacaran, Ura Formation, Siberia.

Discussion.-As noted in a previous section, these distinctive, if possibly incomplete specimens superficially resemble vase-shaped protists found widely in Cryogenian rocks (Porter and Knoll, 2000, and references therein); however, the Ura fossils are taphonomically distinct from known VSMs, indicating an original wall composition far different from those of VSMs. The affinities of these fossils are unknown; foraminifera (e.g., Hua et al., 2010) provide one comparison; nematode egg cysts another, perhaps less likely, possibility.

\section{UNNAMED FORM 3}

Figure 9.9

Description.-Vesicles opaque to darkly translucent, spheroidal to ellipsoidal, surrounded by outer membrane open to one side with an irregular, sharp margin. Membrane translucent, with parallel folds, walls fine- to medium-grained, outer surface texture mediumgrained. Vesicle diameter 125-190 $\mu \mathrm{m}(\mathrm{x}=155 \mu \mathrm{m}, \sigma=19 \mu \mathrm{m}, \mathrm{V}=12 \%, \mathrm{n}=9)$, outer 
membrane is $145-245 \mu \mathrm{m}$ across $(\mathrm{x}=205 \mu \mathrm{m}, \sigma=31 \mu \mathrm{m}, \mathrm{V}=15 \%, \mathrm{n}=9)$ and up to 300-250 $\mu \mathrm{m}$ long; space separating vesicle and membrane is 30-120 $\mu \mathrm{m}$.

Material examined.-Twenty seven poorly-to medium-preserved vesicles.

Discussion.-Like all microfossils described in this group, unnamed form 3 exhibits poor preservation that precludes confident identification.

\section{UNNAMED FORM 4}

Figure 7.8, 7.8a

(Part) Trachyhystrichosphaera aff. aimika HERMAnN in TimOfEev, HERMAnN, AND

MiKhailova, 1976. NAgOvitsin, FAizUllin, And YaKschin, 2004, p. 14, pl. 1, figs. 7, $10,11$.

Trachyhystrichosphaera sp. FAIZULLIN, 1998, pl. 1, fig. 16.

? Miroedichia lobata FAIZULLin, 1998, p. 332, pl. 1, fig. 6; NAGOVITSIN, FAIZULLIN, AND

YAKSCHIN, 2004, pl. 1, figs. 5, 6.

Description.-Spheroidal vesicles with distinct inner and sometime partially preserved outer layers. Few to many irregularly distributed processes arise from the inner wall and extend beyond the outer layer, when available. Inner layer opaque, probably coarse-grained; outer layer thick, translucent, medium- to coarse-grained or missing. Processes heteromorphic: either hollow and cylindrical, translucent, separated from vesicle interior, and bent down a few times with broken tips (no completely preserved processes observed) or dark, solid, bristle-like, with closed tips gathered in bunches and commonly surrounded by an outer translucent layer. Diameter of vesicle 200-220 $\mu \mathrm{m}$, cylindrical processes about $4 \mu \mathrm{m}$ wide, 10 to more $80 \mu \mathrm{m}$ long, either supporting the outer layer or protruding beyond it; bristle-like processes $1-2 \mu \mathrm{m}$ wide and 10-12 $\mu \mathrm{m}$ long.

Material examined.-Three partially preserved specimens. 
Discussion.--In the presence of processes that arise from an inner vesicle and either support or erupt through an enclosing outer vesicle, Unnamed form 4 resembles the TonianCryogenian (Late Riphean or Uchuromayan-Yuzhnouralian units cf. Sergeev, 2009) index taxon Trachyhystrichosphaera aimika. Indeed, Nagovitsin et al. (2004) identified similar Ura microfossils as Trachyhystrichosphaera aff. aimika, leading them to the biostratigrphic conclusion that Ura beds were Cryogenian (Baikalian or Late Riphean) in age. Unnamed form 4, however, differs decisively from T. aimika in the presence of a second type of hairlike processes.

We also include here in questionable synonymy the form described by Faizullin (1998) as Miroedichia lobata. These fossils do not fit the diagnosis of Miroedichia as erected by Hermann (Yankauskas, 1989, p. 45) or emended by Faizullun (1998, p.332). Miroedichia specimens display processes that expanding toward their tips, a diagnostic feature not recorded by material illustrated by Faizullin (1998) and Nagovitsin et al. (2004), or encountered in this present study. As the Ura fossils cannot be assigned to the earlier Neoproterozoic genus Miroedichia, they cannot be used to argue for a Crygenian age for Ura deposition.

\section{UNNAMED FORM 5}

Figure 9.5, 9.6

Description._-Vesicles translucent to opaque, spheroidal to ellipsoidal, but basically irregular, triangular or polygonal in plane view with broken or fringed margins; vesicle surface texture medium-grained. Vesicles surface covered with sinuous, anastomosing canallike features that impart a net-like texture to the vesicles. Vesicle dimensions 140x200 $\mu \mathrm{m}$ to 315x425 $\mu \mathrm{m}$ (mean diameter=275 $\mu \mathrm{m} ; \sigma=75 \mu \mathrm{m}, \mathrm{V}=27 \%, \mathrm{n}=7$ ); canal-like features $2-10 \mu \mathrm{m}$ wide ( $\mathrm{x}=5 \mu \mathrm{m}, \sigma=2 \mu \mathrm{m}, \mathrm{V}=40 \%, \mathrm{n}=100)$ and $10-80 \mu \mathrm{m}$ long. 
Material examined.-Seven poorly-preserved vesicles with well-preserved invaginations.

Discussion.-With some uncertainty, we interpret the canal-like features on these vesicle surfaces as secondary features, perhaps made by heterotrophic decomposers. That the features have negative rather than positive relief, their irregular nature, and the fact individual canals commonly in blindly rather than in contact with another canal all support a diagenetic origin. Similar features were earlier reported on the surfaces of Myxococcoides cell walls from the Mesoproterozoic Kotuikan and Yusmastakh formations, Anabar Uplift, Siberia (Sergeev et al., 1995; Sergeev, 2006).

\section{ACKNOWLEDGMENTS}

We thank K. Grey and E. J. Javaux for constructive reviews of the manuscript and helpful taxonomic remarks. We also thank N. M. Chumakov, M. A. Semikhatov and M. A. Fedonkin for numerous helpful discussions. Research support provided in part by RFBR Grants \# 10-05-00294, \# 11-05-00234 and the Program of the Presidium of Russian Academy of Sciences \# 25. AHK’s research supported by NASA grant NNX07AV51G.

\section{REFERENCES}

AitKen, J. D. 1978. Revised models for depositional Grand Cycles, Cambrian of the southern Rocky Mountains, Canada. Bulletin of Canadian Petroleum Geology, 26: $515-542$. 
AllaRd, B. AND J. TEMPLIER. 2000. Comparison of neutral lipid profile of various trilaminar outer cell wall (TLS)-containing microalgae with emphasis on algaenan occurrence. Phytochemistry, 54:369-380.

ANDREW, T. E. AND A. HERZIG. 1984. The respiration rate of the resting eggs of Leptodora kindti (Focke 1844) and Bythotrephes longimanus Leydig 1860 (Crustacea, Cladocera) at environmentally encountered temperatures. Oecologia, 64:241-244.

Arouri, K., P. F. GreEnWOOD, AND M. R. WALTER. 1999. A possible chlorophycean affinity of some Neoproterozoic acritarchs. Organic Geochemistry, 30:1323-1337.

Arouri, K., P. F. Greenwood, AND M. R. WALter. 2000. Biological affinities of Neoproterozoic acritarchs from Australia: microscopic and chemical characterization. Organic Geochemistry, 31:75-89.

BEARDALL, J. 2009. Allometry and stoichiometry of unicellular, colonial, and multicellular phytoplankton. New Phytologist, 181:295-309.

Belova, M. Yu. AND V. K. GolOVENOK. 1999. Late Riphean mineralized microfossils from the Valyukhta Formation of the Baikal-Patom Highland. Stratigraphy and Geological Correlation, 7:105-115.

Blades-Eckelbarger, P. I. AND N. H. MARCus. 1992. The origin of cortical vesicles and their role in egg envelope formation in the spiny eggs of a calanoid copepod, Centropages velificatus. Biological Bulletin, 182:41-53.

Bobrov, A. K., 1964. Geology of the Cis-Baikalian border trough. Structure and perspectives for oil content. Nauka, Moscow, 227 p. (In Russian)

Braenm, F. 1911. The variation in the statoblast of Pectinella magnifica. Archiv für Entwicklungsmechanik der Organismen, 32:314-348.

CHUMAKov, N. M. 1959. Stratigraphy and geology of the southern-west part of Vilyi Depression. Tectonics of the U.S.S.R. 4. Nauka, Moscow, 460 p. (In Russian) 
CHuMakov, N. M. 2001. Periodicity of major glaciations events and their correlation with endogenic activity of the Earth. Doklady Earth Sciences, 379:507-510.

Chumakov, N. M., B. G. Pokrovskit, And V. A. Melezhik. 2007. Geological history of the Late Precambrian Patom Supergroup (Central Siberia). Doklady Earth Sciences, 413:343-346.

Chumakov, N. M., I. N. Kapitonov, M. A. Semikhatov, M. V. Leonov, And S. V. Rud’ko. 2011. Vendian age of the upper part of the Patom Complex in middle Siberia: U/Pb LA_ICPMS dates of detrital zircons from the Nikol'skoe and Zherba formations. Stratigraphy and Geological Correlation 19:233-237.

Cohen, P. A., A. H., KNOLL, AND R. B. Kodner. 2009. Large spinose microfossils in Ediacaran rocks as resting stages of early animals. Proceedings of the National Academy of Sciences, U.S.A., 106:6519-6524.

Condon, D., Y. ZhU, S. Bowring, W. WANG, A. H. YANG, AND Y. G. Jin. 2005. U-Pb ages from the Neoproterozoic Doushantuo Formation, China. Science, 308:95-98.

DERRY, L. A. 2010. A burial diagenesis origin for the Ediacaran Shuram-Wonoka carbon isotope anomaly. Earth and Planetary Science Letters, 94:152-162.

EliÁš, M., Y. NĚMCOVÁ, P. ŠKALOUd, J. NEUSTUPA, V. KAUfNEROVÁ, AND L. ŠEJNOHOVÁ. 2010. Hylodesmus singaporensis gen. et sp. nov., a new autosporic subaerial green alga (Scenedesmaceae, Chlorophyta) from Singapore. International Journal of Systematic and Evolutionary Microbiology, 60:1224-1235.

EviTT, W. R. 1963. A discussion and proposals concerning fossil dinoflagellates, hystrichospheres, and acritarchs, I. Proceedings of the National Academy of Sciences, U.S.A., 49:158-164.

FaizulLin, M. S. 1998. New data on Baikalian microfossils of the Patom Upland. Russian Geology and Geophysics, 3:328-337. (In Russian) 
GolovenoK, V. K. 1957. Stratigraphy of the northern part of Patom Upland. Vestnik LGU (Proceedings of Leningrad State University), 4:54-64. (In Russian)

GolovenoK, V. K. And M. Yu. Belova. 1983. Obruchevellids from the Riphean of the Patom Highland and the Vendian of southern Kazakhstan. Doklady Academii Nauk SSSR, 272:1462-1465. (In Russian)

GolubKOVA, E. Y. AND E. G. RAEvSKAYA. 2007. Lower Vendian complex of microfossils from the interior part of the Siberian platform, p. 39-41. In The Rise and Fall of the Vendian (Ediacaran) Biota. Origin of the Modern Biosphere. Transactions of the International Conference on the IGCP Project 493. GEOS, Moscow. (In Russian)

GolubKova, E. Y., E. G. RAevskAyA, AND A. B. KuZNETSOV. 2010. Lower Vendian microfossil assemblages of East Siberia: significance for solving regional stratigraphic problems. Stratigraphy and Geological Correlation, 18:353-375.

Gravestock, D. I., J. G. G. Morton, AND W. L. ZANG. 1997. Biostratigraphy and correlation, p. 87-97. In J. G. G. Morton and J. F. Drexel (eds.), Petroleum Geology of South Australia, Volume 3: Officer Basin. South Australia. Department of Mines and Energy Resources Report Book 97/19.

GRAZHDANKIN, D. V. 2003. Structure and depositional environment of the Vendian Complex in the southeastern White Sea area. Stratigraphy and Geological Correlation, 11:313331.

GREY, K. 1999. A modified palynological preparation technique for the extraction of large Neoproterozoic acanthomorphic acritarchs and other acid insoluble microfossils. Geological Survey of Western Australia Record 10, 23 p.

GREY, K. 2005. Ediacaran palynology of Australia. Association of Australasian Palaeontologists Memoir 31, 439 p.

GREY, K. AND C. R. CALVER. 2007. Correlating the Ediacaran of Australia. Geological Society, London, Special Publication, 286:115-135. 
GRotZINGER, J. P. 1986. Evolution of Early Proterozoic passive margin carbonate platform, Rocknest Formation, Wopmay Orogen, Northwest Territories, Canada. Journal of Sedimentary Petrology, 56:831-847.

GROTZINGER, J. P. 1989. Facies and evolution of Precambrian carbonate depositional systems: emergence of the modern platform archetype, p. 79-106. In P. D. Grevello, J. L. Wilson, J. F. Sarg, and J. F. Read (eds.), Controls on Carbonate Platform and Basin Development. SEPM Special Publication 44.

Gupta, N. S., R. Michels, D. E. G. Briggs, M. E. Collinson, R. P. Evershed, And R. D. PANCOST. 2007. Experimental evidence for the formation of geomacromolecules from plant leaf lipids. Organic Geochemistry, 38:28-36.

Gupta, N. S., G. D. Cody, O. E. Tetlie, D. E. G. Briggs, And R. E. Summons. 2009. Rapid incorporation of lipids into macromolecules during experimental decay of invertebrates: initiation of geopolymer formation. Organic Geochemistry, 40:589594.

HAGEN, C., S. Siegmund, AND W. BRAUNE. 2002. Ultrastructural and chemical changes in the cell wall of Haematococcus pluvialis (Volvocales, Chlorophyta) during aplanospore formation. European Journal of Phycology, 37:217-226.

HermanN, T. N. 1979. Finds of fungi in Riphean, p. 129-136. In B. S. Sokolov (ed.), Paleontology of the Precambrian and Early Cambrian. Nauka, Leningrad. (In Russian)

HERmanN, T. N. 1981. Filamentous microorganisms of the Lakhanda beds, the Maja River. Paleontologicheskii zhurnal, 2: 94-97. (In Russian)

Hermann, T. N. 1990. Organic World a Billion Years Ago. Nauka, Leningrad, 50 p. (In Russian)

HILL, R. E. AND W. D. SHEPARD. 1997. Observations on the identification of California anostracan cysts. Hydrobiologia, 359:113-123. 
HuA, H., Z. Chen, X. L. YuAn, S. H. XIAO, AND Y. P. CAI. 2010. The earliest Foraminifera from southern Shaanxi, China. Science China, Earth Science, 53:1756-1764.

JAVAUX, E., A. H. KNOLL, AND M. R. WALTER. 2004. TEM evidence for eukaryotic diversity in mid-Proterozoic oceans. Geobiology, 2:121-132.

Khomentovsky, V. V., K. T. NAgovitsin, And A. A. Postnikov. 2008. Mayanian (1100850 Ma)—Prebaikalian Upper Riphean of Siberia. Russian Geology and Geophysics, 49:1-22. (In Russian)

Khomentovsky, V. V., A. A. Postnikov, G. A. Karlova, B. B. Kochnev, M. S. YAKSCHIN, AND V. A. PonOMARChUK. 2004. The Vendian of the Baikal-Patom Upland, Siberia. Russian Geology and Geophysics, 45:430-448. (In Russian) Khomentovsky, V. V., V. Yu. Schenfl', M. S. Yakschin, And V. G. Pyatiletov. 1972. The reference sections of upper Precambrian and Lower Cambrian deposits along the southern margin of the Siberian Platform. Nauka, Moscow, 356 p. (In Russian)

KNOLL, A. H. 1992. Vendian microfossils in metasedimentary cherts of the Scotia Group, Prins Karls Forland, Svalbard. Palaeontology, 35:751-774.

KNOLL, A. H. 1994. Proterozoic and Early Cambrian protists: evidence for accelerating evolutionary tempo. Proceedings of the National Academy of Sciences, U.S.A., 91:6743-6750.

Kodner, R., A. H. Knoll, And R. E. Summons. 2009. Phylogenetic investigation of the aliphatic, non-hydrolysable biopolymer algaenan, with a focus on the green algae. Organic Geochemistry, 40:854-862.

Kolosov, P. N. 1982. Upper Precambrian paleoalgae remain from the Siberian Platform. Moscow, Nauka, 93 p. (In Russian)

Kolosova, S. P. 1991. Late Precambrian thorny microfossils of the east of the Siberian Platform. Algologia, 39:53-59. (In Russian)

LemmermanN, E. 1904. Das plankton schwedischer Gewässer. Arkiv für Botanik, Band 2, 
2:1-209.

Livshic, V. I., A. I. IVAnOV, V. K. GolovenoK, AND B. V. YABlonovsKiI. 1995.

Stratigraphy. Proterozoic, p. 72-145. In Precambrian of the Patom Upland. Nedra, Moscow. (In Russian)

MARCUS, N. H. AND F. BOERO. 1998. Minireview: the importance of benthic-pelagic coupling and the forgotten role of life cycles in coastal aquatic systems. Limnology and Oceanography, 43:763-768.

Marshall, C. P., E. J. JavauX, A. H. KnOll, AND M. R. WAlter. 2005. Combined microFourier transform infrared (FTIR) spectroscopy and micro-Raman spectroscopy of Proterozoic acritarchs: a new approach to palaeobiology. Precambrian Research, 138:208-224.

Martin, M. W., D. V. Grazhdankin, S. A. Bowring, D. A. D. Evans, M. A. Fedonkin, AND J. L. KIRSCHVINK. 2000. Age of Neoproterozoic bilatarian body and trace fossils, White Sea, Russia: implications for metazoan evolution. Science, 288:84-845.

McFadden, K. A, S. Xiao, C. Zhou, G. Xie, J. D. SchiffBauer. 2006. DoushantuoPertatataka acritarchs in Ediacaran successions of South China: preservational bias or ecological control? Geological Society of America, Abstracts with Programs, 38:303. McFadden, K. A., J. Huang, X. L. Chu, G. Q. Jiang, A. J. Kaufman, C. M. Zhou, X. Yuan, AND S. XIAO. 2008. Pulsed oxidation and biological evolution in the Ediacaran Doushantuo Formation. Proceedings of the National Academy of Sciences, U.S.A., 105:3197-3202.

Melnikov, N. V. (ed.) 2005. Stratigraphy of oil and gas basins of Siberia. Riphean and Vendian of Siberian platform and its folded border. Novosibirsk, Academic Publishing House “Geo”, 428 p. (In Russian) 
Mikhailova, N. S. 1986. New finds of the microfossils from the Upper Riphean deposits of the Krasnoyarsk region, p. 31-37. In Current Problems of Modern Paleoalgology. Nauka, Kiev. (In Russian)

MissarzHEVSKII, V. V. 1989. The oldest shelly fossils and the stratigraphy of the Precambrian-Cambrian boundary deposits. Nauka, Moscow, 237 p. (In Russian) MocZYDŁOWSKA, M. 2005. Taxonomic review of some Ediacaran acritarchs from the Siberian Platform. Precambrian Research, 136:283-307.

MoczydŁowsKA, M. 2008. New records of late Ediacaran microbiota from Poland. Precambrian Research, 167:71-92.

MoczydŁowSKA, M. 2010. Life cycle of Early Cambrian microalgae from the Skiagiaplexus acritarchs. Journal of Paleontology, 84:216-230.

MoczydŁowsKa, M., G. VidAL, AND V. A. RudAVSKAYA. 1993. Neoproterozoic (Vendian) phytoplankton from the Siberian Platform, Yakutia. Palaeontology, 36:495-521. MoczydŁowsKa, M., J. W. SCHOPf, AND S. WiLlMAN. 2010. Micro- and nano-scale ultrastructure of cell walls in Cryogenian microfossils: revealing their biological affinity. Lethaia, 43:129-136.

NAGOVITSin, K. E., M. Sh. FAizullin, AND M. S. YAKSCHIN. 2004. New forms of Baikalian acanthomorphytes from the Ura Formation of the Patom Uplift, East Siberia. Russian Geology and Geophysics, 45:7-19. (In Russian)

Niblack, T. L., K. N. LAmBert, AND G. L. TylKA. 2006. A model plant pathogen from the kingdom animalia: Heterodera glycines, the soybean cyst nematode. Annual Review of Phytopathology, 44:283-303.

ONOUE, Y., T. TODA, AND S. BAN. 2004. Morphological features and hatching patterns of eggs in Acartia steueri (Crustacea, Copepoda) from Sagami Bay, Japan. Hydrobiologia, 511:17-24. 
Pokrovskit, B. G., V. A. MelezhiK, AND M. I. BujAKAITE. 2006. Carbon, oxygen, strontium, and sulfur isotopic compositions in late Precambrian Rocks of the Patom Complex, Central Siberia: Communication 1. Results, isotope stratigraphy, and dating problems. Lithology and Mineral Resources, 41:450-474.

PorTER, S. M. AND A. H. KNOLL. 2000. Testate amoebae in the Neoproterozoic Era: evidence from vase-shaped microfossils in the Chuar Group, Grand Canyon. Paleobiology, 26:360-385.

Porter, S. M., R. Mesterfeld, AND A. H. KnOLL. 2003. Vase-shaped microfossils from the Neoproterozoic Chuar Group, Grand Canyon: a classification guided by modern testate amoebae. Journal of Paleontology, 77:409-429.

Pyatiletov, V. G. 1980. The Yudomian assemblage of microfossils of South Yakutia. Russian Geology and Geophysics, 21:8-20. (In Russian)

Pyatiletov, V. G. 1983. Late Precambrian and Early Paleozoic stratigraphy of Central Siberia, p. 115-121. In The Southwestern Border of the Siberian Platform. IGiG SO AN SSSR, Novosibirsk. (In Russian)

Pyatiletov, V. G. And V. A. RudavsKaya. 1985. Acritarchs of the Yudoma Complex, p. 151-158. In B. S. Sokolov and A. B. Ivanovskii (eds.), The Vendian System 1, Palaeontology, Nauka, Moscow. (In Russian) (English Translation published in 1990, The Vendian System, Volume 1. Springer-Verlag, Berlin, p. 179-188)

RudAVsKaya, V. A. AND N. J. VAsiL’EVA. 1989. Talsy assemblage of acritarchs from the Nepa-Botuoba Anteclise, p. 5-11. In N. A. Timoshina (ed.), Phytostratigraphy and spore morphology of the ancient plants in the oil-gas provinces in the U.S.S.R. Vsesoyuznyi Nefteyanoi Nauchno-Issledovatelskii Geologorazvedochnyi Institut (VNIGRI), Leningrad. (In Russian)

SALOP, L. I. 1964. Geology of the Baikalian folded area. Stratigraphy 1. Nedra, Moscow, 515 p. (In Russian) 
SCHEPELEVA, E. D. 1962. Plant (?) remains of unknown systematic position from the Bavlinskaya Group of the Volga-Ural Oil Province. Doklady AN SSSR, 142:456-457. (In Russian)

SCHOPf, J. W. 1968. Microflora of the Bitter Springs Formation, Late Precambrian, Central Australia. Journal of Paleontology, 42:651-688.

SCHOPF, J. W. AND J. M. BLACIC. 1971. New microorganisms from the Bitter Springs Formation (late Precambrian) of the North-Central Amadeus Basin, Australia. Journal of Paleontology, 45:925-960.

SERGEEV, V. N. 2006. Precambrian microfossils in cherts: their paleobiology, classification, and biostratigraphic usefulness. GEOS, Moscow, 280 p. (In Russian)

SeRgeEV, V. N. 2009. The distribution of microfossil assemblages in Proterozoic rocks. Precambrian Research, 173:212-222.

Sergeev, V. N., A. H. Knoll, And J. P. Grotzinger. 1995. Paleobiology of the Mesoproterozoic Billyakh Group, Anabar Uplift, northeastern Siberia. Paleontological Society Memoir 39, 37 p.

Sergeev, V. N., M. A. Semikhatov, M. A. Fedonkin, And N. G. Vorob'eVa. 2010. Principal stages in evolution of Precambrian organic world: communication 2. The Late Proterozoic. Stratigraphy and Geological Correlation, 18: 561-592.

SoviETOV, YU. K. 2002. Vendian foreland basin of the Siberian cratonic margin:

Paleopangean accretionary phases. Russian Journal of Earth Sciences, 4:363-387.

TALYZINA, N. AND M. MoczYdŁOWSKA. 2000. Morphological and ultrastructural studies of some acritarchs from the Lower Cambrian Lukati Formation, Estonia. Review of Palaeobotany and Palynology, 112:1-21.

Tappan, H. 1980. The Paleobiology of Plant Protists. Freeman, W. H., San Francisco, 1028 p. 
Timofeev, B. V. And T. N. HeRman. 1979. Precambrian microbiota of the Lakhanda Formation. In B. S. Sokolov (ed.), Paleontology of the Precambrian and Early Cambrian. Nauka, Leningrad, p. 137-147. (In Russian)

Timofeev, B. V., T. N. Herman, And N. S. Mikhailova. 1976. Microphytofossils from the Precambrian, Cambrian and Ordovician. Nauka, Leningrad, 106 p. (In Russian)

TIWARI, M. AND A. H. KNOLL. 1994. Large acanthomorphic acritarchs from the Infrakrol Formation of the Lesser Himalayas and their stratigraphic significance. Himalayan Geology, 5:193-201.

VAN WAVERN, I. AND N. H. MARCUS. 1993. Morphology of recent copepod egg envelopes from Turkey Point, Gulf of Mexico, and their implications for acritarch affinity. Special Papers in Paleontology, 48:111-124.

Veis, A. F., N. G. Vorob’eVA, And E. Yu. GolubKovA. 2006. The early Vendian microfossils first found in the Russian Plate: taxonomic composition and biostratigraphic significance. Stratigraphy and Geological Correlation, 14:368-385.

VolKOva, N. A. 1985. Acritarchs and other plant microfossils of the East-European Platform, p. 130-139. In B. S. Sokolov and A. B. Ivanovskii (eds.), The Vendian System 1, Palaeontology, Nauka, Moscow. (In Russian) (English translation published in 1990, The Vendian System, Volume 1. Springer-Verlag, Berlin, p. 155-165.)

Volkova, N. A., V. V. Kirjanov, L. V. Piskun, L. T. Paskeviciene, And T. V.

YanKAUSKAs. 1979. Plant microfossils. In B. M. Keller and A. Yu. Rozanov (eds.), Upper Precambrian and Cambrian Palaeontology of the East-European Platform. Nauka, Moscow, p. 4-38. (In Russian) (English translation published in 1983, A. Urbanek and A.Yu. Rozanov (eds.), Upper Precambrian and Cambrian Palaeontology of the East-European Platform. Publishing House Wydawnictwa Geologiczne, Warsaw, Poland, p. 7-45). 
Vorob’eva, N. G., V. N. Sergeev, And M. A. Semikhatov. 2006. Unique Lower Vendian Kel'tma microbiota, Timan Ridge: new evidence for the paleontological essence and global significance of the Vendian System. Doklady Earth Sciences, 410:1038-1043. Vorob’eva, N. G., V. N. Sergeev, And A. H. Knoll. 2007. Microfossil assemblages from the Vychegda Formation of the East European Platform passive margin—a biostratigraphic model for the Upper Riphean (Crygenian)/Vendian (Ediacaran) boundary, p. 42-46. In The Rise and Fall of the Vendian (Ediacaran) Biota. Origin of the Modern Biosphere. Transaction of the International Conference on the IGCP Project 493. GEOS, Moscow.

Vorob’eva, N. G., V. N. Sergeev, And N. M. Chumakov. 2008. New finds of early Vendian microfossils in the Ura Formation: revision of the Patom Supergroup age, Middle Siberia. Doklady Earth Sciences, 419:782-787.

Vorob’eva, N. G., V. N. Sergeev, AND A. H. KnOlL. 2009a. Neoproterozoic microfossils from the northeastern margin of the East European Platform. Journal of Paleontology, 83:161-192.

Vorob’eva, N. G., V. N. Sergeev, AND A. H. KnOLL. 2009b. Neoproterozoic microfossils from the margin of the East European Platform and the search for a biostratigraphic model of lower Ediacaran rocks. Precambrian Research, 173:163-169.

WELLMAN, C. H. 2002. Morphology and wall ultrastructure in Devonian spores with bifurcate-tipped processes. International Journal of Plant Sciences, 163:451-474.

WiLlman, S. AND M. MoczYDŁOWSKA. 2007. Wall ultrastructure of an Ediacaran acritarch from the Officer Basin, Australia. Lethaia, 40:111-123.

WILLMAN, S. AND M. MocZYDŁOWSKA. 2008. Ediacaran acritarch biota from the Giles 1 drillhole, Officer Basin, Australia, and its potential for biostratigraphic correlation. Precambrian Research, 162:498-530. 
Willman, S., M. MoczydŁoWsKA, AND K. GREY. 2006. Neoproterozoic (Ediacaran) diversification of acritarchs_-a new record from the Munaroo 1 drillcore, eastern Officer Basin, Australia. Review of Palaeobotany and Palynology, 139:17-40.

XiAO, S. AND A. H. KNOLL. 2000. Phosphatized animal embryos from the Neoproterozoic Doushantuo Formation at Weng'an, Guizhou Province, South China. Journal of Paleontology, 74:767-788.

YANKAUSKAS, T. V. 1980. On the micropaleontological characteristics of the Middle and Upper Cambrian in the north-west of the East European Platform. Izvestiya Akademiya Nauk Estonskoyi SSR, Geology, 19:131-135. (In Russian)

YANKAUSKAS, T. V. (ed.). 1989. Precambrian microfossils of the U.S.S.R. Trudy Instituta Geologii i Geochronologii Dokembria SSSR Akademii Nauk. Nauka, Leningrad, 188 p. (In Russian)

YAN, Y. 1982. Schizofusa from the Chuanlinggou Formation of Changchen System in Jixian County. Bulletin of the Tianjin Institute of Geology and Mineral Resources, 6:1-7.

YIN, C. Y., S. BENGTSON, AND Z.YUE. 2004. Silicified and phosphatized Tianzhushania, spheroidal microfossils of possible animal origin from the Neoproterozoic of South China. Acta Palaeontologica Polonica, 49:1-12.

YIN, L. 1985. Microfossils of the Doushantuo Formation in the Yangtze Gorge District, western Hebei. Palaeontologia Cathayana, 2:229-249.

YIN, L. 1986. Sinian microfossil plants from the Yangtzee region. Dicengxue Zazhi (Journal of Stratigraphy), 4:262-269. (In Chinese)

YIN, L. 1987. Microbiotas of latest Precambrian sequences in China. Stratigraphy and Palaeontology of Systemic Boundaries in China, Precambrian-Cambrian Boundary, 1: 415-494.

YIN, L. and Z. Li. 1978. Precambrian microfossils of Southwest China. Memoir, Nanjing Institute of Geology and Palaeontology, Academica Sinica, 10:41-102. (In Chinese) 
Yin, L., M. Zhu, A. H. Knoll, X. YuAn, J. Zhang, AND J. Hu. 2007. Doushantuo embryos preserved inside diapause egg cyst. Nature, 446:661-663.

YIN, L., M. ZhU, AND X. YUAN. 2008. New data on Tianzhushania-an Ediacaran diapause egg cyst from Yichang, Hubei. Acta Palaeontologica Sinica, 47:129-140. (In Chinese)

YuAn, X. AND H. J. HofMANN. 1998. New microfossils from the Neoproterozoic (Sinian) Doushantuo Formation, Wengan, Guizhou Province, southwestern China. Alcheringa, 22:189-222.

ZANG, W. AND M. R. WALTER. 1992. Late Proterozoic and Cambrian microfossils and biostratigraphy, Amadeus Basin, central Australia. Association of Australasian Palaeontologists Memoir 12, 132 p.

Zhang, Y., L. Yin, S. XiaO, AND A. H. KNOLL. 1998. Permineralized fossils from the terminal Proterozoic Doushantuo Formation, South China. Paleontological Society Memoir 50, 52 p.

Zhou, C., G. Xie, K. McFadden, S. Xiao, And X. Yuan. 2007. The diversification and extinction of Doushantuo-Pertatataka acritarchs in South China: causes and biostratigraphic significance. Geological Journal, 42:229-262. 
FIGURE CAPTIONS

Figure 1-A, map of the southeastern margin of the Siberian Platform (Patom Uplift area), showing locations of the Ura anticline (filled square at arrow); $B$, geological map of the region delineated by the box in A, showing the Ura anticline and the outcrop location of the fossiliferous Ura Formation beds considered here (shown by arrow).

Figure 2-Generalized stratigraphic column of the Neoproterozoic (Cryogenian through Ediacaran) and Cambrian deposits of the Patom Uplift area (A); Ts=Tirbess Fm.; Nk=Nokhtuisk Fm.; Mc=Macha Fm.; some stratigraphic schemes incorporate the Tirbess Formation into the Tinnaya Formation. Asterisk denotes the Ura acritarch assemblage; diamond denotes the Nemakitian-Daldynian fauna (Anabarites trisulcatus and (?)Purella antiqua zones); square denotes the Tommotian fauna (Ajacicyathus sunnaginicus Zone); unconformities marked by a wavy line. Sample numbers with adjacent filled squares indicate the stratigraphic levels of the fossiliferous samples studied (B).

Figure 3-Microfossil taxa reported here from the Ura Formation, indicating their morphologial grouping, relative abundance $(\mathrm{R}=\mathrm{rare}, \mathrm{C}=\mathrm{common}, \mathrm{D}=$ dominant), and size range (displayed on a logarithmic scale). Asterisk marks additional forms reported by Nagovitsin et al., 2004; double asterisk marks forms reported by Faizullin, 1998.

Figure 4-1-3, Ancorosphaeridium magnum: 1, 2-2005-11-17-12, Q30[3], 14701-464; 2, 2a, detail of 2, 2-2005-12-3-3, M51[1], 14701-484; 3, 3a, detail of 3, holotype, 2-2005-12-3-2, J57[0], 14701-483; 4, 5, Ancorosphaeridium minor; 4, 4a, detail of 4, holotype, 2-2005-11-93, O61[4], 14701-363; 5, 2-2005-11-17-4, O61[1], 14701-456. Single scale bar=10 $\mu \mathrm{m}$, double bar=50 $\mu \mathrm{m}$. 
Figure 5-1-3, Appendisphaera sp.: 1, 2-2005-9-4-1, E59[1], 14701-196; 2, 2a, detail of 2, 2-2005-8-15-9, T69[4], 14701-155; 3, 2-2005-8-2-6, R62[2], 14701-75; 4-6, Appendisphaera tenuis: 4, 4a and 4b, details of 4, 2-2005-10-6-6, Q63[4], 14701-293; 5, 5a, detail of 5, 2-2005-10-5-9, O52[3], 14701-284; 6, 6a, detail of 6, 2-2005-10-1-1, J55[4], 14701-258; 7, 7a, detail of 7, Bullatosphaera velata, 2-2005-9-14-4, O54[0], 14701-243. Single scale bar $=10 \mu \mathrm{m}$, double bar $=50 \mu \mathrm{m}$.

Figure 6-1, 2, Tanarium conoideum: 1, 2-2005-8-13-3, L67[2], 14701-136; 2, 2-2005-7-5-1, M62[2], 14701-39; 3, Tanarium tuberosum, 2-2005-8-14-7, O58[3], 14701-147; 4-6, Variomargosphaeridium litoschum: 4, 2-2005-9-6-1, K55[1], 14701-205; 5, 2-2005-8-12-9, S60[4], 14701-133; 6, 2-2005-8-10-3a, O58[0], 14701-111; 7-9, Archaeotunisphaeridium aff. Fimbriatum: 7, 2-2005-11-1-3b, N62[0], 14701-334; 8, 8a, detail of 8, 2-2005-8-17-2, L60[1], 14701-162; 9, 2-2005-8-6-5, L60[1], 14701-90. Single scale bar=10 $\mu \mathrm{m}$, double bar $=50 \mu \mathrm{m}$.

Figure 7-1, 1a and 1b, details of 1, Ancorosphaeridium magnum, 2-2005-12-3-1, G50[1], 14701-482; 2-4, ?Sinosphaera rupina: 2, 2-2005-9-10-1, G58[0], 14701-224; 3, 2-2005-820-1, K62[1], 14701-176; 4, 4a, detail of 4, 2-2005-9-1-2, J53[4], 14701-180; 5, 5a, detail of 5, Knollisphaeridium maximum, 2-2005-9-13-3, J64[0], 14701-236; 6, Tanarium digitiformum, 2-2005-11-17-5, N61[4], 14701-457; 7, Gyalosphaeridium minutum, 2-2005-825-10, R66[4], 14701-509; 8, 8a, detail of 8, unnamed form 4, K63[0], 2-2005-9-13-5, 14701-238. Single scale bar $=10 \mu \mathrm{m}$, double bar=50 $\mu \mathrm{m}$. 
Figure 8-1-5, Dicrospinasphaera virgata:1, $1 a$ and 1b, details of 1, 2005-11-9-4, R59[1], 14701-364; 2, 2a, detail of 2, 2-2005-10-21-1, M69[1], 14701-514; 3, 2-2005-10-11-1, M56[4], 14701-319; 4, 2-2005-11-9-2, L66[3], 14701-362; 5, 5a and 5b, details of 5, 2-200511-1-3a, N62[0], 14701-333. Single scale bar=10 $\mu \mathrm{m}$, double bar=50 $\mu \mathrm{m}$.

Figure 9-1, 4, Eotylotopalla strobilata:1, 2-2005-8-4-1, M-67[1], 14701-81; 4, 4a, detail of 4, 2-2005-9-11-2, L59[2], 14701-230; 2, 3, unnamed form 2; 2, 2a, detail of 2, 2-2005-10-65b, P73[2], 14701-292; 3, 2-2005-10-6-5a, X72[4], 14701-291; 5, 6, unnamed form 5; 5, 22005-11-17-1, K64[0], 14701-453; 6, 2-2005-10-9-2, K65[1], 14701-306; 7, Aimia aff. A. gigantica, 2-2005-10-5-8, N63[2], 14701-283; 8, Schizofusa zangwenlongii, 2-2005-8-2-4, N67[4], 14701-73; 9, unnamed form 3, 2-2005-8-7-4, Q55[4], 14701-95. Single scale bar=10 $\mu \mathrm{m}$, double bar $=50 \mu \mathrm{m}$.

Figure 10-1, 3, 6, Rugosoopsis tenuis: 1, 2-2005-8-16-3, K33[1], 14701-158; 3, 2-2005-1111-15, W56[0], 14701-383; 6, 2-2005-12-14-1, H71[3], 14701-512; 2, Cavaspina cf. C. acuminata, 2-2005-11-7-4, O55[0], 14701-354; 4, 5, Segmentothallus aff. Asperus: 4, 22005-12-16-2, J52[0], 14701-510; 5, 2-2005-12-11-3, L71[3], 14701-511; 7, Ceratophyton sp., 2-2005-9-5-3, U63[3], 14701-204; 8, cf. Cucumiforma sp., 2-2005-11-6-1, M67[2], 14701-350; 9, unnamed filamentous microfossils, 2-2005-8-25-11, Q70[0], 14701-513; 10, Siphonophycus spp., 2-2005-9-16-3, S55[2], 14701-252; 11, unnamed form 1, 2-2005-8-8-1, J60[3], 14701-96. Single scale bar=10 $\mu \mathrm{m}$, double bar=50 $\mu \mathrm{m}$. 


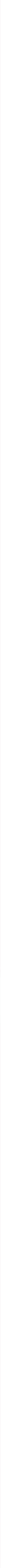




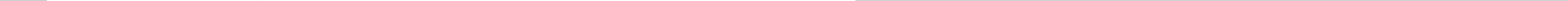




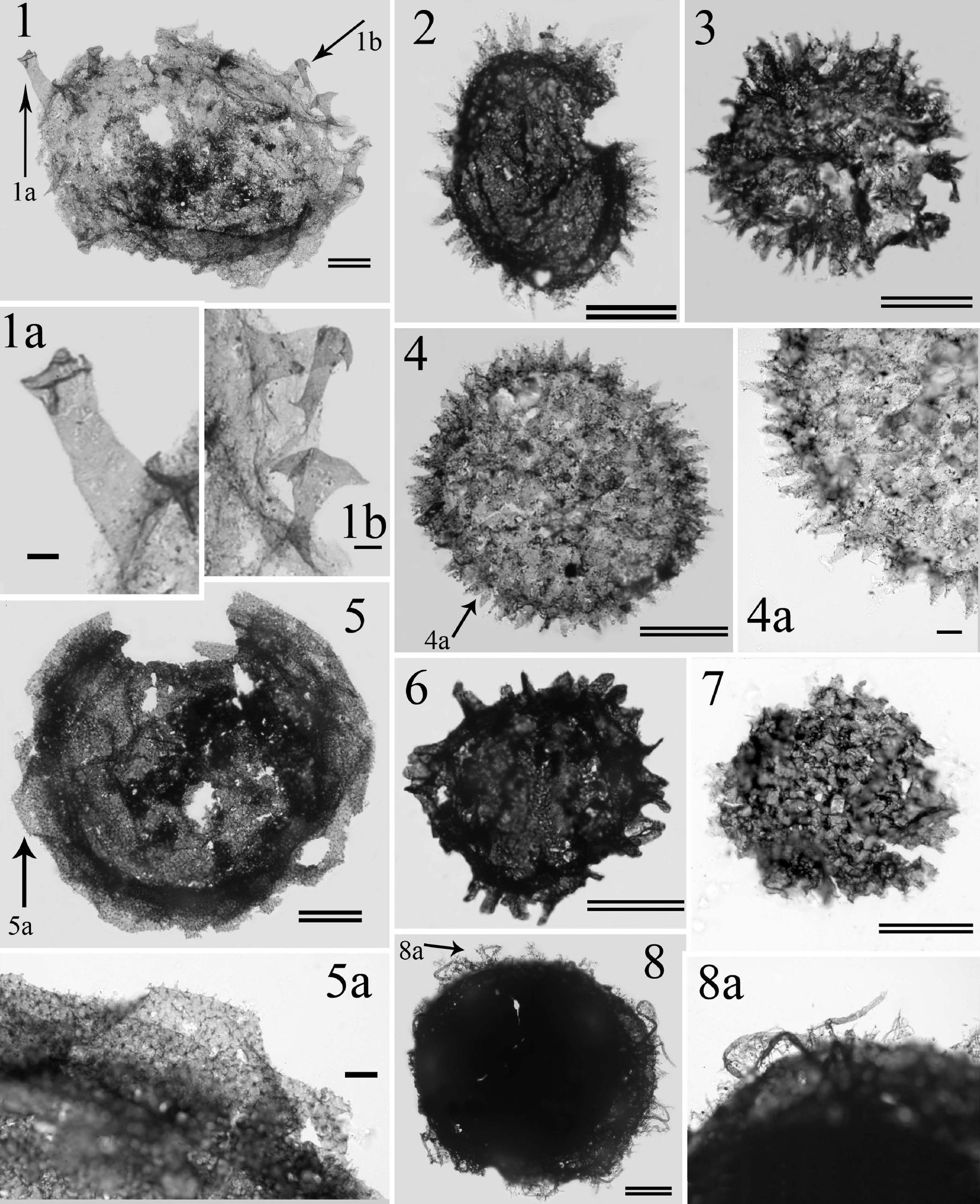




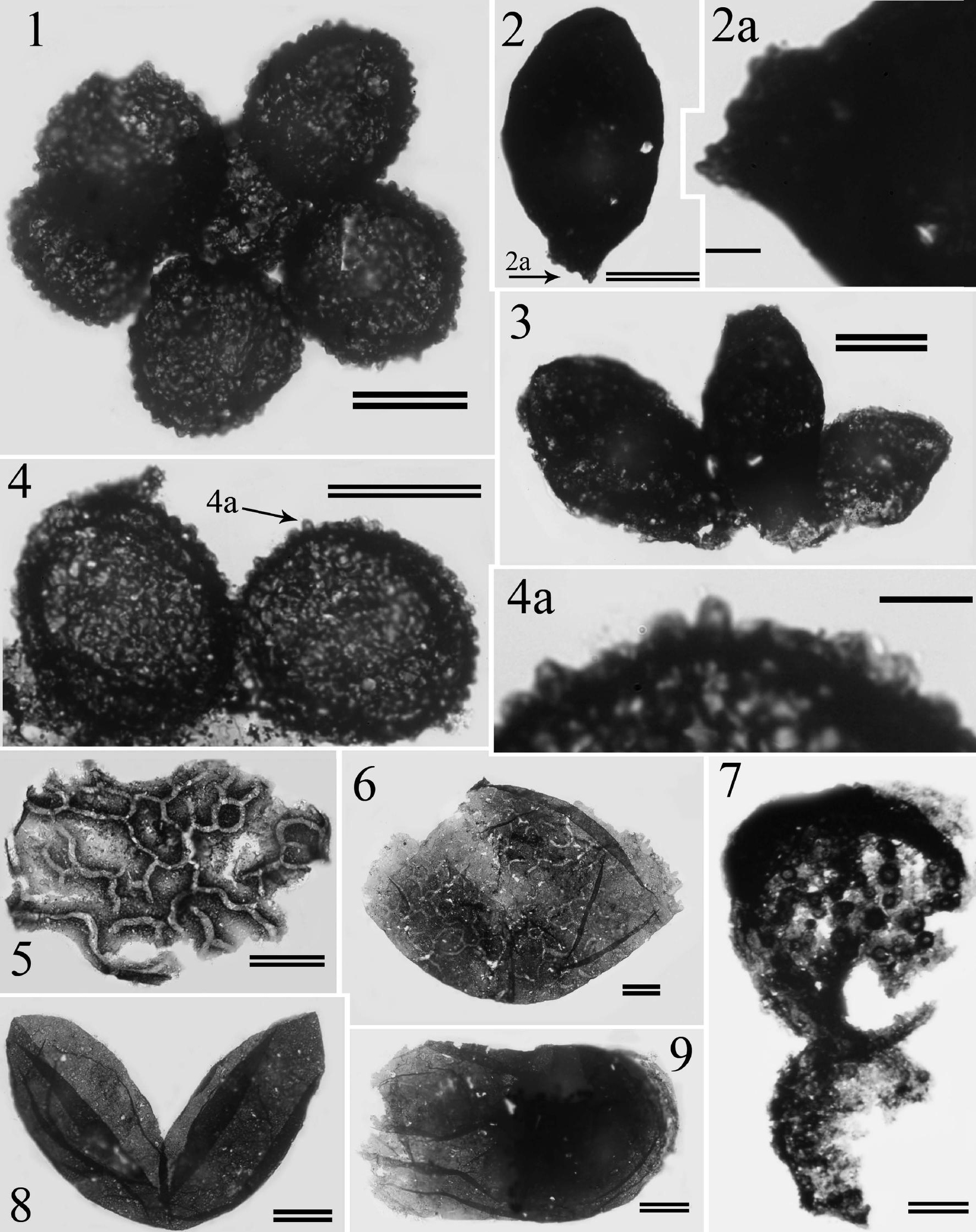

